\title{
A morphological revision of the earliest horned nectridean from the Pennsylvanian of England and Ireland
}

\begin{tabular}{|r|l|}
\hline Journal: & $\begin{array}{l}\text { Earth and Environmental Science Transactions of the Royal Society of } \\
\text { Edinburgh }\end{array}$ \\
\hline Manuscript ID & Draft \\
\hline Manuscript Type: & Early Vertebrate Evolution \\
\hline Date Submitted by the Author: & n/a \\
\hline Complete List of Authors: & Milner, Angela; The Natural History Museum, Earth Sceinces \\
\hline Keywords: & $\begin{array}{l}<\text { i }>\text { Keraterpeton }</ i>\text {, anatomy, evolution, functional morphology, } \\
\text { systematics }\end{array}$ \\
\hline \multicolumn{2}{|l}{} \\
\hline
\end{tabular}




\title{
A morphological revision of the earliest horned nectridean from the Pennsylvanian of England and Ireland
}

\author{
Angela C. Milner \\ Department of Earth Sciences \\ The Natural History Museum \\ Cromwell Road \\ London SW7 5BD
}

A.Milner@nhm.ac.uk

Running head

Keraterpeton from the Pennsylvanian of England and Ireland 


\begin{abstract}
The aquatic diplocaulid nectridean Keraterpeton galvani, is the commonest taxon represented in the Jarrow Coal assemblage from Kilkenny, Ireland. The Jarrow locality has yielded the earliest known Carboniferous coal-swamp fauna in the fossil record and is therefore of importance in understanding the history and diversity of the diplocaulid clade. The morphology of Keraterpeton is described in detail with emphasis on newly observed anatomical features. A reconstruction of the palate includes the presence of interpterygoid vacuities andnew morphological details of the pterygoid, parasphenoid and basicranial region. The hyoid apparatus comprising a basibranchial element has not been reported previously in nectrideans. The structure of the scapulocoracoid and primitive nature of the humerus is described and the presence of a five digit manus confirmed. Previously unrecognised accessory dermal ossifications are present in the pectoral girdle. Keraterpeton longtoni from the Bolsovian in Staffordshire, England, is also described and newly figured. The primitive condition in diplocaulids is defined on the basis of the earliest occurrence at Jarrow and discussed in relation to functional morphology and mode of life. The evolution of the diplocaulid clade is assessed in relation to the revised diagnoses that define the primitive condition in Keraterpeton.
\end{abstract}

KEYWORDS: Keraterpeton, anatomy, evolutiorn functional morphology, systematics. 
The Nectridea is a clade of small, mostly aquatic tetrapods occurring in the Lower Pennsylvanian to Permian of North America, Europe and Morocco comprising three families; Urocordylidae, Diplocaulidae, and Scincosauridae. Most were less than $500 \mathrm{~mm}$ long with relatively short trunks and long tails and possessed characteristic holospondylous vertebrae with fused neural and haemal arches and spines. Expanded fan-shaped haemal spines conferred a long, laterally flattened tail that was adapted primitively for anguilliform swimming. Nectrideans were traditionally grouped together with microsaurs and aïstopods as Lepospondyli on the basis of the shared one-piece membrane bone vertebra (Carroll et al. 1998). However, the phyletic unity of lepospondyls was questioned by Thomson \& Bossy (1970) and Bossy (1976) who suggested that holospondylous vertebrae are the product of functional convergence and the lepospondyl concept is no longer considered valid by recent workers.

The diplocaulids or horned nectrideans, are distinguished by long posteriorly or posterolaterally directed tabular horns. The Lower Pennsylvanian diplocaulids, together representatives of the urocordylids and aiistopods were members of equatorial coal-swamp assemblages in Europe and North America. The earliest occurrence is the Langsettian fauna from Jarrow Colliery, Kilkenny, Ireland. The Jarrow locality is thus of great historical importance to the understanding and interpretation of coal-swamp assemblages (A. R. Milner 1980). Huxley \& Wright's 1867 description of the Jarrow amphibians was the first detailed account of a coal-swamp assemblage and provided the basis for interpreting the later Westphalian D late Middle Pennsylvanian coal swamp fauna from Linton, Ohio, first discovered in the 1850's (Newberry 1867).

Little has been published on the Jarrow nectrideans since Huxley \& Wright's 1867 monograph apart from a brief review by Milner (1980) and a comparative review of the Nectridea by Bossy \& Milner (1998). The diplocaulid Keraterpeton galvani is the commonest of the 11 taxa identified in the Jarrow assemblage (Sequeira 1996). A detailed morphological account is given here drawing on unpublished data from Milner 1978 and additional specimens subsequently made available for study. A second species, Keraterpeton longtoni from the Bolsovian (Westphalian C) of the North Staffordshire Coalfield, is described and newly figured.

Specimens are held in the following institutions; British Geological Survey (BGS), Sedgwick Museum of Earth Sciences, University of Cambridge (CAMSM), Geological Survey of Ireland (GSI), The Natural History Museum, London (NHMUK), National Museum of Ireland New Geology Collection (NMING), National Museums of Scotland (NMS), Trinity College Dublin (TCD), Warwickshire Museums Service (WARMS), Museum of Comparative Zoology, Harvard (MCZ).

\section{THE JARROW CARBONIFEROUS COAL SWAMP FAUNA}

\subsection{History of discovery and collection.}

Amphibian fossils were first discovered and collected in 1864 by W. B. Brownrigg from Jarrow Colliery in Kilkenny, Republic of Ireland. He identified six or seven forms that he presumed were reptiles (Brownrigg 1865). The fossils derived from shales roofing a deep oxbow in the Jarrow Coal seam, the so-called 'Jarrow Channel', lying $64 \mathrm{~m}$ below ground. The Jarrow Coal was worked from 1853 but until 1864 had produced only occasional fossil ferns although anecdotal reports of 'large lizards and snakes with feet' date back to 1858 (Bailey 1881). Brownrigg communicated his findings to E. P. Wright of Trinity College Dublin, anticipating joint collaboration on the material. Wright then procured a grant from 
the British Association to fund further collecting of plants, fishes, and additional amphibian specimens. Nonetheless, Wright simultaneously invited T. H. Huxley to describe the material (Wright \& Huxley 1866; Huxley \& Wright 1867). In doing so, Wright side-lined Brownrigg who had expected to be involved in the scientific description of his finds but acquiesced in favour of Huxley. Wright's behaviour caused resentment, conflict of interests, and overrode potential priority claims of local geologists (Wyse Jackson et al. 2011). Brownrigg was sufficiently disaffected and aggrieved by the whole affair that he abandoned geology (DeArce et al. 2011). He sold his personal collection of 92 blocks containing fishes and amphibians to the British Museum (Natural History) in January 1870. A note appended to the original batch number register entry, NHMUK PV OR 41851, indicates that many were subsequently destroyed because of pyrite decay. A total of c. 120 identifiable tetrapods specimens are recorded in the collections of the institutions listed above.

\subsection{Geology and preservation}

The Jarrow Coal Formation is dated as Langsettian (Westphalian A) in the lower part of the communis zone (Nevill 1956, Eagar 1961, 1964). Higgs \& O’Conner (2005) confirmed on palynological grounds that the Jarrow seam lies above the SS - RA miospore biozonal boundary that correlates closely with the boundary of the lenisulcata and communis nonmarine bivalve chronozones. The Jarrow seam, $35 \mathrm{~cm}$ deep, extends over 51.7 square $\mathrm{km}$ of the Leinster Coalfield expanding into an oxbow 167-251 metres wide and $1.2 \mathrm{~m}$ deep (Hallissy 1939). The whole lake basin is u-shaped cross-section $14 \mathrm{~m}$ deep and represents an abandoned channel (Hook \& Ferm 1988). Unusually, the Jarrow the channel is infilled with anthracite and cannel coal (Kendall 1923). The amphibian and fish fossils derive from bright coal and carbonaceous shales in millimetre laminae overlying the anthracite coal. The matrix is pyrite rich and Jarrow specimens are poorly and variably preserved although usually as articulated individuals. The bone is subject to pyrite decay, mobilization and replacement of calcium phosphate $\mathrm{Ca}^{3}\left(\mathrm{PO}^{4}\right)^{2}$ by calcite and/or prismatic apatite crystals and sphalerite $(\mathrm{Zn}, \mathrm{Fe}) \mathrm{S}$ that collapses the bone structure (Rayner 1971). Extensive dissolution results in bituminous residues with indistinct outlines as noted by Huxley \& Wright (1867, p. 354) and ultimately low resolution 'ghost' moulds. Rayner (1971) concluded that the interstitial waters of the lake bottom sludge were intermittently sufficiently acid to cause the diagenetic changes that degrades anatomical detail and hinders interpretation of the material. The usual technique for preparation of coal fossils, acid etching and casting the resulting high fidelity moulds, is thus not applicable to the Jarrow material. Fine surface films of cannel were removed where possible under a binocular microscope with an S. S. White industrial abrasive using fine grade calcium dolomite powder (Stucker 1961).

\section{SYSTEMATIC PALAEONTOLOGY}

\section{Emended diagnosis}

ORDER Nectridea Miall 1875

Small Palaeozoic tetrapods with a relatively short trunk, between 14 and 26 presacral vertebrae, and a long, usually laterally compressed tailNo otic notch and no stapes known. Prefrontal contacts external naris in majority of taxa, palatal fangs absent. Intertemporal absent. Postorbital - parietal contact (except Scincosauridae) and parietal - tabular contact. Braincase largely cartilaginous but opisthotic long and well ossified where known. Single coronoid and splenial in lower jaw. Cleithrum present primitively. Vertebrae holospondylus with single spool- shaped centra fused to neural and haemal arches. Atlas vertebra with reduced neural spine. Neural spines rectangular to fan-shaped, ornamented with longitudinal 
grooves and distal crenelations. Haemal spines expanded and bearing similar ornament. At least one pair of accessory articulations present above the zygapophyses between vertebrae in trunk and proximal region of tail. Limbs relatively small, manus and pes with five digits where known.

Family Diplocaulidae Cope 1881

(= Ceraterpetontidae Jaekel 1903.

Keraterpetontidae Jaekel, emend. Romer 1945)

\section{Emended diagnosis}

Nectridean amphibians with broad moderately to strongly flattened akinetic skulls with cheek and skull table firmly sutured. Skull with short snout and long postorbital region. Nasal participates in the posteromedial border of the naris. Intertemporal and supratemporal absent. Frontals paired primitively. Large parietal contacting frontal, postfrontal, squamosal, tabular and postparietal. Tabular large with long posteriorly or posterolaterally directed horn.

Squamosal with an internal flange contacting quadrate. Quadrate anterior to occiput. Sutural connection between parasphenoid, exoccipitals and basioccipital. Mandible short with short marginal tooth row, primitively with 10-12 teeth. Retroarticular process present on surangular. Single Meckelian fenestra in mandible. Dermal ornament a shallow pit and ridge system. Lateral line canals present. Short trunk with a maximum of 17 presacral vertebrae. Neural arches of presacral vertebrae never waisted, haemal arch insertion always symmetrically waisted. Haemal spine articulation a simple overlap where present. Elongate rectangular to triangular clavicle plates. Cleithrum ' $\mathrm{T}$ '-shaped primitively. Unossified carpals and tarsals.

Included taxa: Batrachiderpeton, Diceratosaurus, Diploceraspis, Diplocaulus, Keraterpeton.

Genus Keraterpeton Huxley in Wright \& Huxley 1866

(= Urocordylus Miall 1875 non Wright \& Huxley 1966, Ceraterpeton Cope 1875, Keratespeton Oldham 1876 in errore, Ceraterpetum Lydekker 1890, Keraterpetum Andrews 1895)

\section{Diagnosis}

Primitive characters with respect to all other diplocaulids.

Maxilla excluded from orbit margin by lacrimal - jugal contact. Nasal contributes to posteromedial border of the naris. Squamosal margin concave, similar in area to parietal and extends onto the lateral tabular horn base. Postparietal border straight. Parasphenoid with long cultriform process contacting vomers. Basibranchial present. Elongate dorsally directed retroarticular process on surangular. Seventeen presacral vertebrae. Dorsal neural spines, twice as tall as wide. Dorsal edge of neural spines bear ridged, striate to slightly rugose ornament. Caudal vertebrae lack zygantrum-zygosphene articulations and neural and haemal spines slightly waisted. Haemal spines wider than centra and overlap along the tail. Haemal spines wider than centra. Long tapering tail with a whip-like end in which spine heights gradually reduce distally to small centra only. Simple crescentic humerus.

Primitive characters shared with Diceratosaurus

Prefrontal reaches external naris margin. Cultriform process on parasphenoid and small interpterygoid vacuities present. Tabular horns straight and parallel. Cleithrum with short rounded anterior process lying in close proximity to the posterior end of the tabular horn and 
long posterior process with straight dorsal margin. Paired extra dermal ossifications lateral to clavicles. Distal caudal vertebrae with waisted haemal arches.

Primitive characters shared with Diceratosaurus and Batrachidepeton

Postorbital contributes to posterior margin of orbit. Dermal ornament a pit and ridge system. Proximal caudal vertebrae with haemal arches inserted along full length of centrum and overlapping haemal spines.

Distribution. England, Republic of Ireland; Langsettian - Moscovian, Pennsylvanian. Included species. Type species Keraterpeton galvani, Keraterpeton longtoni.

\subsection{Keraterpeton galvani Wright \& Huxley, 1866}

Diagnosis. As for genus plus postorbital with narrow insertion on orbit margin and elongate posterior contact inserting between parietal and sqamosal. Parietal - squamosal suture convex. Transverse lateral line sulcus follows squamosal parietal suture. Skull table slightly longer than pre-parietal region of skull. Three pairs of caudal ribs usually present.

Holotype. NMING F14735 (ex GSI B.2866). The largest known individual in dorsal aspect lacking the tail. Length $170 \mathrm{~mm}$ as originally preserved (Fig. 1A). The proximal caudal vertebrae and hind limb has since been lost and the specimen is embedded in and covered by paraffin wax to combat pyrite decay (pers. comm., N.T. Monaghan) (Fig. 1B). The species was named for the collector Charles Galvan of the Geological Survey of Ireland. Huxley proposed the name in November 1865, in reply to a letter from J. B. Jukes Director of the Geological Survey of Ireland (GSI) returning a sketch sent to him by Galvan.

Locality. Jarrow Colliery, Castlecomer, Clough County, Kilkenny, Ireland.

Horizon. Jarrow Coal, Coolbaun Coal Formation, Leinster Coalfield, Westphalian A, Langsettian.

Referred material. BGS 12107, presented by James George Robertson in 1889, originally to the Royal School of Mines. Ghost impression of skull, trunk and disarticulated hind limb elements in dorsal aspect.

BGS 26842 (ex a 6 XVII 2), presented by James George Robertson in 1889 (originally to the Royal School of Mines). Skull in dorsal aspect figured Steen (1938, figs 9c, 10) with associated but detached pectoral girdle.

CAMSM A.5969 (Walton Collection, 16w.) Skull figured Steen (1938, pl.2, fig.3) trunk and proximal five caudal vertebrae in dorsal aspect. Length $115 \mathrm{~mm}$.

CAMSM E.14378 (Walton Collection, unnumbered). Ghost impression of skull and skeleton including proximal caudal vertebrae figured Oldham (1876 pl. vii). Originally in the Rugby

School Natural History Collection. Length ca. $140 \mathrm{~mm}$.

CAMSM E.14379. Skull in ventral aspect with complete vertebral column with complete tail. Length ca. $200 \mathrm{~mm}$.

CAMSM E.14380 (Walton Collection, 8w). Skull and trunk in dorsal and ventral aspect mounted in glass. Length ca. $70 \mathrm{~mm}$.

CAMSM E.19869 (Walton Collection, 17w). Skull and trunk in dorsal view plus five associated articulated posterior dorsal vertebrae. Length $74 \mathrm{~mm}$.

CAMSM E.19870 (Walton Collection, 2w). Ghost impression of skull and anterior postcranium in ventral aspect. Length ca. $70 \mathrm{~mm}$.

CAMSM E.19871 (Walton Collection, 3w). Fragmentary skull and vertebral column including ca. 23 caudal vertebrae. Length c. $150 \mathrm{~mm}$.

CAMSM E.19872 (Walton Collection, 33w). Skull anterior trunk and pectoral girdle in ventral aspect. Length $61 \mathrm{~mm}$. 
NHMUK PV R 8452, purchased from William Bookey Brownrigg, 1870. Skeleton in dorsal aspect complete to third caudal vertebra. Length $165 \mathrm{~mm}$.

NHMUK PV R 8457, purchased from William Bookey Brownrigg, 1870. Skeleton in ventral aspect including hind limb and proximal caudal vertebrae as impressions. Length $116 \mathrm{~mm}$. NHMUK PV R 8460, purchased from William Bookey Brownrigg, 1870. Poorly preserved skull, trunk and proximal caudal vertebrae. Length $80 \mathrm{~mm}$.

NHMUK PV R 8472, purchased from William Bookey Brownrigg, 1870. Counterpart impression of NHMUK PV R 8460.

NMING F14711 (ex G1-1970), presented by Joseph Dobbs, 1890. Poorly preserved skull and trunk in ventral aspect*.

NMING F14212 (ex G2-1970), presented by Joseph Dobbs, 1890. Poorly preserved skull and trunk in dorsal aspect*.

NMING F14714 (ex G4-1970), presented by Joseph Dobbs, 1890. Poorly preserved ghost impression of skull fragments and trunk*.

NMING F14715 (ex G5-1970, poorly preserved ghost impression*.

NMING F14734 (GSI collection)**

NMING F14742 (GSI collection)**

NMING F16888**

NMS 1950.56.6, well-preserved specimen originally with complete tail. Figured Woodward (1897, pl.12).

TCD F70 (ex NMING F14694, G47-1959). Skeleton in ventral aspect figured Huxley \& Wright (1867, pl. 19, fig. 2).

TCD R252 (ex NMING F14695, G48-1959, T252/426). Skeleton preserved in ventral aspect complete to 16th caudal vertebra. Length ca. $167 \mathrm{~mm}$.

TCD 38352 (ex NMING F14696, ex G G49-1959). Skull in dorsal aspect, trunk and proximal five caudal vertebrae in left lateral aspect. Length $127 \mathrm{~mm}$.

WARMS Gz 2470. Fragmentary vertebral column and hind limb.

WARMS Gz 2780. Postcranial fragments on small blocks.

MCZ 2193, presented by E. P. Wright. Skeleton in ventral and lateral aspect, complete to $6^{\text {th }}$ caudal vertebra. Length $155 \mathrm{~mm}$.

* no accurate measurements possible

** not examined

\subsection{Keraterpeton longtoni Milner, 1998}

(= Urocordylus wandesfordii Wright \& Huxley, Miall 1875 non Wright \& Huxley 1866; Keraterpeton galvani Wright \& Huxley, Ward 1890 non Wright \& Huxley 1866)

Diagnosis. As for genus plus - postorbital squarish with a broad insertion on orbit margin and short parietal contact. Parietal squamosal suture concave. Transverse lateral line sulcus crosses squamosal. Cranial lateral line sulci present as pronounced pits including transverse occipital and infraorbital pit-lines. Skull table slightly shorter than pre-parietal region of skull. Dorsal edges of neural spines with markedly coarsely rugose ornament.

Holotype. NHMUK PV R 2395 presented J. Ward 1891. Skull and partial postcranial skeleton preserved in dorsal aspect. Skull figured Ward (1890: pl. ix, fig. 2); Andrews (1895 fig. 1); Steen (1938: text-fig. 9a, pl. 2, fig. 1); Milner (1978, figs 22-25 [unpublished thesis]). Locality. Longton Hall Colliery, Longton, Staffordshire, England.

Horizon. Rowhurst Coal, known locally as the Ash Coal, Westphalian C, Middle Coal Measures, Bolsovian, Moscovian, Pennsylvanian (Rees \& Wilson 1998). Noted by Ward (in 
Gibson et al. 1905) as a bluish-black shale intercalated with a thin band of ironstone overlying the Ash Coal.

Material. Known from holotype only.

\subsection{Keraterpeton ?longtoni}

Locality. Fenton Colliery, Fenton, Staffordshire, England.

Horizon. Winghay Coal, otherwise known as the Knowles Coal, from an ironstone band termed the 'Knowles Ironstone', Westphalian C, Middle Coal Measures, Bolsovian, Pennsylvanian (Rees \& Wilson 1998).

Material. NHMUK PV R 8967 (acquisition history unknown). Four articulated dorsal vertebrae, two of which are shattered with an embedded impression of a large tooth indicating probable predation. Not diagnostic but may belong to $K$. longtoni since the dorsal edges of neural spines bear identical coarsely rugose ornament.

\section{DESCRIPTION}

\subsection{General proportions of the skeleton}

Almost complete skeletons are preserved in NMS 1950.56.6 and CAMSM E.14379.

Woodward (1897, pl. 12) figured the skeleton of NMS 1950.56.6 in ventral aspect with 49 or 50 caudal vertebrae but only the proximal 25 now remain. The distal portion of the tail was lost during a subsequent remounting of the block in a wooden frame (pers. obs.). Based on Woodward's figure, the proportions of the skull: trunk: tail are 1:3.5:7, the entire skeleton being about $170 \mathrm{~mm}$ long (Fig. 2). The articulated tail of an otherwise poorly preserved $200 \mathrm{~mm}$ long individual, CAMSM E. 14379, includes c. 53 caudal vertebrae. Accurate overall dimensions are not possible for most specimens because of the variable effects of preservation and crushing but the ratio of skull length to trunk length falls within the range of 1: 3.0-3.5. Midline skull lengths range from to c. $20-40 \mathrm{~mm}$ in K. galvani giving estimated total length range from c. $170 \mathrm{~mm}$ to $400-420 \mathrm{~mm}$.

\subsection{Skull}

3.2.1. Skull roof. The holotype of $K$. galvani NMING F14735, is the largest recorded individual with a skull length of c. $40 \mathrm{~mm}$ (Fig. 1). Skull lengths in other individuals range between $20-29 \mathrm{~mm}$. The major features of the skull roof are depicted in Huxley \& Wright's original figure (1867, pl. 19, fig. 1) but the specimen is unavailable for detailed study (see 2.1 above). The skull roof in dorsal aspect is broadly triangular in shape with a rounded snout. The posterolateral borders of the skull table bear parallel straight sided slender and posteriorly directed tabular horns. The skull roof description is based principally on BGS 26842 (Fig. 3) with a skull length of c. $28.5 \mathrm{~mm}$ unless otherwise indicated. K. longtoni is represented by a single smaller individual with a midline skull length of c. $15 \mathrm{~mm}$ (NHMUK PV R 2395, Fig. 4). The snout region is broad, shallow and squared off anteriorly with subterminal external nares. The orbits are large, slightly oval in shape and dorsolaterally oriented. The deep cheek region is triangular in shape and describes a shallow curve with the margin of the skull table. It describes an almost $90^{\circ}$ concave curve to the lateral margin of the tabular, which it meets on a line slightly medial to the lateral snout margin. The cheek region is preserved flattened in the same plane as the skull table in the majority of specimens. In some individuals it is fractured along the mid length of the orbit - the line of least resistance in the skull roof - and crushed flat against the palate. 
The dermal ornament of the skull roof is a uniformly distributed pit and ridge system. The centre of ossification of each bone is marked by deep pitting that radiates out as elongated ridges along the lines of growth. In K. longtoni (NHMUK PV R 2395) the pitting is uniformly deeper and more densely distributed and runs in distinct furrows to the margins of the mid-line elements.

The right premaxilla preserves four conical marginal teeth (see section 3.2.3.), is rectangular in shape and the posterolateral margin borders the external naris. Steen (1938, fig.9C) depicted the premaxilla as the same length as the nasal, but is only half as long in the midline. The maxilla is slender and splint-like and the marginal teeth are sharply conical ; five anterior ones plus a gap are present on the left side (see section 3.2.5). The right maxilla is slightly displaced at its anterior end exposing the broad overlapping suture with the premaxilla on the lateral margin of the external naris. The maxilla is excluded from the orbit margin by the lacrimal and jugal.

The nasal is short and broad anteriorly where it borders the medial narial margin and narrow posteriorly. The frontal is long and narrow with parallel lateral and medial margins and a length-width ratio of $3: 1$.

The parietal is the largest element in skull roof with convex lateral margins so that posterior width is 2.5 times the anterior width in contrast to Steen's $(1938$, figs. 9B,10) interpretation of the parietals as comparatively parallel-sided. The parietal contacts the frontal and postfrontal anteriorly and forms the posterolateral margin of the postorbital. The contact with the squamosal posterolaterally and the postparietal and tabular posteriorly effectively preclude any kinesis between the skull table and cheek. The parietal is narrower with a concave lateral margin in K. longtoni NHMUK PV R 2395 (Fig. 4). The postparietal is rectangular in shape with a straight posterior margin and a smooth convex ridge curving ventrally towards the occiput. The dorsal aspect of the exoccipitals are exposed beyond posterior margin of the postparietals and tabulars, although not well preserved.

The prefrontal is long and slender and contacts the posterior narial margin in CAMSM A.5969 (Fig. 5). The postfrontal borders the posteromedial margin of the orbit and contacts the prefrontal, frontal, parietal and postorbital (Figs 3, 5). The postorbital is elongate with a narrow neck inserting on the posterior orbit margin contra Steen's figure (1938, figs 9C, 10) of a wide insertion occupying most of the posterolateral orbit margin. A long posterior process carrying the temporal sulcus forms a v-shaped contact between the parietal and squamosal. The postorbital is short and square In K. longtoni (NHMUK PV R 2395 Fig. 4) with a small posteromedial parietal contact. The lacrimal borders the posterior margin of the external naris and the anterior margin of the orbit and sutures narrowly with the jugal on the lateral orbit margin.

The slender anterior process of the jugal borders the lateral orbit margin and contacts the postorbital medially. The right jugal is displaced laterally in CAMSM A.5969 (Fig. 5) exposing a long overlapping contact with the lacrimal. It has a long lateral sloping suture overlying the maxilla and forms the posterior margin of the mouth. It expands postertolaterally with a concave margin at the junction of the snout and the flared out cheek contacting the quadratojugal at the lateral extremity of the cheek and the squamosal posteriorly. The quadratojugal occupies the ventrolateral extremity of the cheek region. The posterior margins form a concave notch with the squamosal contact to accommodate the movement of the mandibular retroarticular process.

The squamosal is very broad anteriorly and comprises an extensive part of the cheek region contacting the jugal, quadratojugal, parietal, postorbital and jugal. The lateral margin is acutely concave from the quadratojugal notch, forming a splint-like contact with the distal margin of the tabular horn base. The tabular contacts the parietal anteriorly, the postparietal medially so that the posterior margin describes a smooth concave curve with the postparietal 
margin of the skull. The anterior part of the tabular extends posteriorly to form the straight parallel sided horn. The lateral margin of the horn is straight and continues anteriorly to contact the squamosal process. Dermal ornament is restricted to the dorsal surface and the posteromedial surface is relatively smooth and lightly striated.

3.2.2. Lateral line system. Traces of the lateral line system is preserved as a combination of pit-lines and grooves. Traces of the left and right supraorbital sulci follow the course of the sutures between the frontals and pre- and postfrontals and traverse laterally across the postorbitals and the jugals, intersecting with anterior end of the temporal sulcus at the mid-point of the postorbitals. The temporal sulcus runs posteriorly following the line of the parietal squamosal suture. The anterior ends of the temporal sulci run posteriorly across the postorbitaIs from the points of intersection with the supraorbital sulci in BGS 2684 (Fig. 3). A more complete lateral line complement is present as deep pit lines in K. longtoni NHMUK PV R 2395 (Fig. 6). The skull roof is split between counterpart slabs which between them include the right infraorbital sulcus and transverse commissure that crosses the tabulars and squamosals. The temporal sulci traverse the squamosals lateral to the parietals, in contrast to $K$ galvani, and it continues posteriorly to intersect with the transverse sulcus that crosses the postparietals and tabulars.

3.2.3. Palate. Few specimens are preserved in ventral aspect and none show a complete undistorted palate, particularly the braincase and occipital regions. The palatal elements are extensively crushed, overlain by the folded right cheek region and mandible in TCD R252 (Fig. 7) or the pectoral girdle plates in MCZ 2193( Fig. 8). The features of the palate are described as viewed, rather than reversed with respect to the dorsal aspect of the skull.

The left maxilla, premaxilla, internal nostril, palatine and vomer are preserved in TCD R252 (Fig. 7), although the sutures between the elements are unclear. The premaxillary tooth count is between four and six and but cannot be determined accurately as only a small trace of the probable midline suture is visible in line with a trace of the midline vomer suture.

The anterior region of the left premaxilla bears a ring of seven or eight small teeth round the rim of the internal nostril margin and two larger ones placed anterolateral to it. The bone preservation of the posterior region is badly degraded and lacks the finished bone surface although the posterior end of the suture with the right vomer is visible. The left palatine lies between the maxilla and jugal laterally and vomer medially. It carried a row of 16 conical teeth (allowing for two gaps) that diminish in size anteriorly towards the premaxillary contact. The palatine does not appear contact the posterior narial margin but preservation is not sufficiently clear.

The palatal ramus of the right pterygoid borders the lateral margin of a small interpterygoid vacuity in MCZ 2193 (Fig. 8) establishing that the palate was not closed, contra Bossy \& Milner 1998. The anterior region is crushed and incomplete, revealing the ventral side of the skull roof and border of the orbit. A medial ridge is preserved, running anteriorly parallel to the cultriform process of the parasphenoid and contacts the vomer although the suture is not clear. The posterior region of the palatal ramus bears fine diagonal parallel striations radiating towards the medial margin marking scars for the insertion of the adductor musculature. No denticle covered area is present, contra Milner 1980 and Bossy \& Milner 1998. The medial margin has a vertical contact with the parasphenoid at the posterior end of the interpterygoid vacuity (see section 3.2.4.). The quadrate ramus appears to have been sheared off distally and a large tongue-like process of smooth bone protrudes posterolaterally. This is interpreted as the distal part of the ramus that has been compressed and rotated to lie in the same plane as the palatal ramus. It overlies most of the quadrate except for the exposed condyles that are separated by deep intercondylar groove. The 
underlying margin of the quadratojugal is visible, marked by a distinct crack that continues anterodistally onto the ventral exposure of the squamosal. The right quadrate ramus is partially exposed in TCD R252 (Fig.7), oriented ventrolaterally and contacts the quadrate with a strongly interdigitating suture. The medial quadrate condyle is still in articulation with the articular glenoid (see 3.2.5.). A reconstruction of the skull in palatal aspect with the pterygoid and quadrate restored in life position is based on TCD R252 and MCZ 2193 (Fig. 9).

3.2.4. Braincase and occiput. The parasphenoid is preserved in MCZ 2193 (Fig. 8). It bears a long parallel sided cultriform process with a square-ended anterior contact with the vomers in the midline. The left basipterygoid process is preserved insitu on the posterolateral region of the cultriform process. The right process is compressed against and articulated with the pterygoid. The parasphenoid baseplate plate is diamond -shaped and sutures with the posteromedial margin of the right pterygoid ramus. The posterior end of the plate is v-shaped and the posterolateral margin shows a long robust interdigitating suture with the anterior margin of the left exoccipital and a midline suture with a poorly preserved basioccipital.

The left occipital condyle is borne on a stout pedestal and the condyle is oriented slightly towards the midline. The contact with the tabular is disrupted by a broken suture and missing segment of bone. A parallel anterior fractured contact with a slightly detached bone fragment is interpreted as a probable paroccipital process of the left opisthotic (Fig. 9) A fragment of the right exoccipital plate is visible together with the oval condyle although the condylar surface is partly eroded.

3.2.5. Mandible. The mandible is straight, sub-parallel, narrowing anteriorly and curving medially towards the symphysis. The lateral surface ornament is identical to that of skull roof. The mandibles are preserved in articulation in several individuals and the long dorsally oriented surangular retroarticular process projects well behind the posterior margin of the cheek. The dentary bears a single row of sharply pointed conical marginal teeth. A complete tooth row is not preserved in any individual but assuming equal spacing there appears to be space for between ten to12 teeth. The posterior end of the left dentary tooth row is exposed anterior to the edentulous dorsal margin in TCD R252 (Fig. 7). Two teeth occupy the same socket indicating possible evidence of tooth replacement previously unreported in diplocaulids. The mesial surface of the dentary is visible in the partially disarticulated mandibles of BGS 26842 (Fig. 3) exposing a shallow widening Meckelian groove and an elongate surangular dorsal crest. The left mandible in TCD R252 (Fig. 7) is preserved in lateral aspect. The splenial has a wide exposure on the mandibular symphysial margin and a long sloping contact with the angular. The angular has a long straight dorsal contact with the dentary and an sloping contact posteriorly with the surangular. The anterodorsal process of the surangular is slightly disarticulated showing the long overlapping contact with the posterior region of the dentary. The glenoid surface of the articular bears prominent rounded facets either side of a deep u-shaped asymmetric embayment accommodating the quadrate condyles. The course of the suture with the surangular is not determinable.

3.2.6. Branchial skeleton. A single basibranchial element in ventral aspect is present in MCZ 2913, located ventral to the parasphenoid (Fig. 10). A basibranchial is known in some basal tetrapods (Witzmann 2013) but is hitherto unrecorded in any nectridean contra Bossy \& Milner 1998. It is a robust rod-like element with a rounded expanded anterior head resembling a roller joint. The head bears deep laterally curving grooves, the left being somewhat compressed. The shaft widens gradually and then expands markedly with a roughened and lightly rugose surface to the point where it is overlain by the left clavicle 
plate. Two ridges run anteroposteriorly from the base of the head offset from the midline between which runs a shallow groove terminating in faint radiating ridges. The morphology bears little resemblance to the basibranchials of basal tetrapods described and figured by Witzmann (2013) other than the overall basic shape of a rod-like shaft with expanded anterior and posterior ends and a ventral groove as described in dvinosaurid and some dissorophid temnospondyls.

\subsection{Postcranial skeleton}

3.4.1. Vertebrae and ribs. The vertebral column has 17 presacral vertebrae (NMING F14735, Fig. 1). Regional variation in the column is negligible, the depth and length of the vertebrae are almost constant with a slight reduction in spine height in the pelvic region (CAMSM A.5969 Fig. 11). The neural arches and spines of the dorsal vertebrae are fused along the full length of the centrum so that adjacent elements are firmly in contact throughout their full height. The neural spines are ornamented with light striations and pitting with thickened ridged dorsal margins bearing prominent indented vertical striations. Transverse processes are positioned anterodorsally on the neural arches adjacent to the anterior zygaphophyses. The postzygapophyses are distinctly larger and overlap the prezygapohyses on each succeeding vertebra and the articulating surfaces between the zygopophyses are horizontal or nearly so. Zygantrum - zygosphene articulations are present above the zygapophyses. The posterodorsal margin of each neural arch is developed into a distinct spine which fits into a corresponding notch on the anterodorsal neural arch margin of the succeeding vertebra. The adjacent edges of the neural spines show additional small complementary indentations above the zygantrum - zygosphene (Fig. 11). The horizontal position of the zygapophyses and the extra articulations lock the vertebrae together minimising dorsoventral flexing but allowing lateral movement between the vertebrae. The atlas vertebra, shown clearly in right lateral aspect K. longtoni NHMUK PV R 2395 (Fig. 4), lacks a transverse process on the neural arch and has double zygantrum- zygosphene articulations with succeeding second dorsal vertebra.

The caudal neural arches and spines are slightly waisted on the proximal centra and the spines abut dorsally between adjacent vertebrae. Haemal arches fused ventrally to the centra are carried along the length of the tail. The haemal spines span the full length of centra and are tightly appressed in the first four post-caudal rib bearers. They have slightly waisted insertions on the centra from the fifth caudal vertebra distalwards. The spines are expanded and fan shaped so that the posterior margins are longer than the centra so that they overlap the spines of the succeeding vertebrae. The overlapping generally follows a consistent sequence with the anterior end of each spine placed to the same side of the posterior end of the preceding spine to facilitate lateral flexibility. The zygapophyses are dorsally placed and rather crescent shaped. The prezygapophyses project anteriorly from a pronounced lateral ridge on the neural arch. The postzygapophyses curve dorsolaterally from the lateral ridge and dorsoventrally at its posterior extremity and almost completely overlap the prezygapophyses (Fig. 12). The haemal arches bear no articulations. Both neural and haemal spines gradually decrease in height distally and become more waisted so that the tail gradually tapers. Traces of low spines persist at least as far as the 22 nd caudal vertebra and the distalmost elements are reduced to notochordal rings forming a whip-like end to the tail (Fig. 2).

Robust curved dorsal ribs are borne by all the post-axial presacral vertebrae gradually becoming shorter and more incurved (Fig. 13). The sacral rib is stout and straight with posteriorly reflexed distal end in NMING G1-1970 (Fig. 14). The sacral vertebra bears a short stout rib and the first three caudals carry sharply reflexed caudal ribs. Two caudal rib bearers are apparent in NMS 1950.56.6 (Fig. 2 ) but other individuals including the holotype 
NMING F:14735 (Fig. 1) possess three pairs. The ribs are double headed with a short tuberculum articulating with the transverse process and a longer capitulum that articulates obliquely either intercentrally or possibly on the posterior region of the preceding centrum although no articular facets are preserved (Fig. 11).

3.4.2. Pectoral girdle and forelimb. The dermal girdle comprises paired cleithra, clavicles and a single median interclavicle. The clavicles and interclavicle overlap in many individuals due to post-mortem distortion. The articulated dermal plates are preserved in ventral aspect In BGS 26842 (Fig. 15). The broad rectangular clavicle plate bears heavily ornamented pits and ridges radiating out from the centre of ossification adjacent to the base of the unornamented dorsal process. The dorsal process arises from the distal margin of the plate slightly more than halfway towards the posterior end. In articulated specimens it slopes posteriorly (Figs 16, 17) to contact the cleithrum. The similarly ornamented interclavicle bears symmetrical depressions for reception of the clavicles. The posterior margin, where completely preserved, is broadly convex. Paired accessory dermal ossifications lateral to the clavicle plates and bearing similar ornament are present in TCD R252 (Fig. 7), MCZ 2913 (Fig. 8), NMING F14696 (Fig. 16) and NHMUK R 8457 (see section 3.5.) They are rather oval in shape with a pointed dorsal apex and have not been observed previously in Keraterpton although they are present in Diceratosaurus brevirostris from the Lower Pennsylvanian assemblage at Linton, Ohio (Jaekel 1903, pl. 5 and pers. obs.)

The cleithrum is T- shaped with a long shaft inclined anteriorly from the perpendicular. The anterior head is short and broadly rounded and is projected posteriorly into a long tapering posterior spur with a straight dorsal margin. The anterior margin of the shaft follows a smooth convex concave to a sharply rounded ventral point. The posterior margin follows a convex curve to intersect with base of the posterior arm of the head. The lateral face of the cleithrum is lightly ornamented. The medial face is smooth and the anterior head and bears a distinct shallow notch in TCD R252 (Fig. 17). The cleithrum shaft lies parallel to the clavicle shaft and the head overlaps its distal margin (NMING F14696, Fig. 16). The posterior tip of the tabular horn lies very close to the anterior process and may have abutted against or fited into the medial face of the notch. The skull is skewed laterally post mortem in several individuals including NMING F 14696 (Fig. 16), suggesting a lack of any fixed osteological connection although presumably there was a connective tissue attachment in life.

The right scapulocoracoid is unusually well preserved in left lateral aspect in TCD R252, partially overlain by the cleithrum shaft although vertical cracks across the shaft reveal the broadly L-shaped outline (Fig. 17). The margins of the dorsal scapular region are almost parallel. The medial margin turns through a $90^{\circ}$ curve demarcating the coracoid region. The coracoid is quite robust with a thick but eroded medial edge. A distinctly raised ridge on the posterior margin demarcates the elongate oval glenoid fossa. The supracoracoid foramen is marked by a distinct pit on the dorsolateral margin of the ridge.

The right humerus is preserved in ventral aspect in TCD R252 (Fig. 17) is $7 \mathrm{~mm}$ long and kidney-shaped with no discernible features or foramina. The articular surfaces are distally placed and the radius and ulna lie in articulation with the entepicondyle.

The radius is shorter than the ulna with a robust shaft and rounded distal condyles. The ulna has a slender shaft and an incompletely preserved flattened asymmetric distal region in TCD R252 (Fig. 17). The radius and ulna are associated with the pectoral girdle in BGS 24682 (Fig. 15) and the proximal end of the ulna bears a small olecranon process.

The carpals are unossified. The digit count is ambiguous in most specimens but five metacarpals are preserved in articulation in MCZ 2193 (Fig. 18) together with some phalanges of digits IV and V. A typed note on the reverse of the accompanying label states, "right manus damaged in preparation; original ?-?-?-4-3" that refers to an excavated area 
between the ulna and radius and the metacarpals. A five digit count is also preserved in NMS 1950.56.6 Fig. 2, contra the four digit manus given in the diagnosis of the Diplocaulidae by Milner (1998, p. 122). The phalanges are slender with short curved unguals. Digit four is the longest and the phalangeal formula is probably 2-3-3-4-3.

3.4.3. Pelvic girdle and hind limb. The dorsally directed iliac blade is rectangular and square ended in ventral aspect and the posterior margin describes a convex curve widening into the baseplate in NMING F14696 (Fig. 19), although it is partly obscured by the right sacral and proximal caudal rib. The most complete hind limb is preserved in ventral aspect in TCD R252 (Fig. 20). The femur is straight with a slender shaft and the distal end is c. $40 \%$ wider than the proximal end. The tibia is robust and slightly curved with a wide proximal end. The shaft narrows distally but is incomplete. The fibula is c. $60 \%$ shorter the tibia with a narrow proximal and distal ends and the shaft curves markedly towards the tibia. The tarsus is unossified. The metatarsals are slender shafted with broad proximal ends and narrower distal ends. The phalanges are relatively long and slender with short curved unguals. Although no complete articulated pes is preserved the phalangeal formula is probably 2-3-?4-3-3.

3.5. Dermal scales. Isolated dorsal scales overly the right scapulocoracoid and a rib in K. galvani BGS 26842 (Fig. 13). They exhibit a pit and ridge ornament identical to the skull roof and pectoral girdle plates and the shape varies from roughly oval to quadrangular. Better preserved dorsal scales are thinly scattered across the anterior trunk region in K. longtoni, NHMUK PV R 2395 (Fig. 4). The shapes vary between rectangular and oval with pitted ornament and crenelated borders. Overlapping rows of small ventral scales between the pectoral and pelvic girdles were figured in TCD F70 by Huxley \& Wright (1867, pl. 19, figs $2,3,4$.). The scales were figured, albeit rather indistinctly, with crenelated edges. Ventral trunk scalation is preserved clearly in NHMUK PV R 8457 covering the right ribs and presacral centra (Fig. 21). The individual scales are rectangular and arranged in overlapping parallel diagonal rows. They are heavily ornamented mirroring the pits and ridges that extend to posterior margins of the scales so that the edges are coarsely denticulate. This specimen also preserves paired triangular shaped extra dermal plates in association with the lateral margins of the clavicles (see section 3.4.2.).

\section{DISCUSSION}

The diplocaulids are characterised by broad, short-snouted akinetic skulls with large tabular bones bearing long posteriorly or posterolaterally directed horns, short trunks, and long tails. They possess broad elongate pectoral girdle plates and unossified carpals and tarsals, adaptations seen in other secondarily aquatic groups of Carboniferous tetrapods (temnospondyls and anthracosaurs) and analogously with modern newts and salamanders (A. R. Milner 1980). The diagnostic characters of the group express the unique morphology of highly specialised predatory aquatic animals. Keraterpeton is the earliest diplocaulid represented in the fossil record and the revised generic diagnostic characters presented herein represent the primitive condition with respect to all other diplocaulids. The presence of a basibranchial element, although preserved in a single individual of $K$. galvani only, and the primitive crescentic humerus are previously undiscovered basal diplocaulid characters. Milner (1980) discussed the jaw mechanics and locomotor adaptations in relation to the skull - pectoral girdle association in Keraterpeton and argued that it functioned in a dual role as a damping mechanism. Minimising lateral head oscillation to support a straight-line approach to prey as a consequence of anguilliform swimming and buffering stress and skull tilting on 
rapid jaw opening of the depressor musculature were both mediated by the tabular - cleithrum connection.

The primitive skull- girdle association is shared with Diceratosaurus from the Westphalian D swamp assemblage at Linton, Ohio. Both genera also share paired extra dermal ossifications lateral to the clavicle plates that conferred extra rigidity to the pectoral girdle and anterior trunk. The primary function in Diceratosaurus was hypothesed to buffer the anterior trunk against hind limb paddling action rather than the anguilliform swimming mode in Keraterpeton (Milner 1980, Bossy \& Milner 1998). The skull -girdle connection was lost in all other diplocaulids in relation posterolateral tabular horn divergence and adaptations to different locomotor patterns and feeding strategies (Bossy \& Miner 1998).

The size range of $K$. galvani at Jarrow is restricted to individuals with a midline skull length of c. $20-40 \mathrm{~mm}$. The size range for the genus is increased to c. $15-40 \mathrm{~mm}$ with the addition of the single specimen of $K$. longtoni from the later Longton locality. Very small diplocaulids are rare in the fossil record. Diplocaulus primus from the Artinskian of Oklahoma is the smallest known individual with a midline skull length of $7.1 \mathrm{~mm}$. Despite being a juvenile, it exhibits a high degree of precocial ossification lacking only ossified carpals and tarsals associated with an aquatic life style (Milner 1996). A Diplocaulus sp. with a mid-line skull length of $8.3 \mathrm{~mm}$ is known from the Texas Early Permian is also a juvenile but well-ossified individual (Chaney et al. 2005). In a growth and variation study of Diplocaulus, Olson (1970) established a ratio of midline skull length to antorbital length ( $<$ five) as diagnostic of Diplocaulus magnicornis. However, he observed values of $>5$ for some skulls less than $24 \mathrm{~mm}$ long and Milner (1996) questioned the diagnostic value of this ratio in small individuals. Nontheless, the wide size range of D. magnicornis skulls, $8.3 \mathrm{~mm}$ - $147 \mathrm{~mm}$, establishes the possible growth range in diplocaulids. Batrachiderpton reticulatum from the Duckmantian coal swamp assemblage in the Northumberland coalfield and with a similar aquatic active predatory lifestyle is represented by specimens with a midline skull length between 16 - 98 mm including well ossified juveniles (Milner 1978). Precocial ossification of the postcranial skeleton at small body size is a developmental pattern that occurs in both fossil and modern groups with holospondylous vertebrae including nectrideans (Carroll 1989) and is suggestive of either direct development or a tiny larval stage of which there is no fossil record. The size range of $K$. galvani from Jarrow might represent a component of a single faunal mass death event. However, the variable state of preservation of individual specimens, combined with the fact that there are no records to indicate if the material came from a single horizon within the Jarrow channel, offers no clues. All that can be surmised is that individuals of between c. $170 \mathrm{~mm}$ to $420 \mathrm{~mm}$ long inhabited the shallow oxbow lake that gave rise to the Jarrow Channel deposit and died either in a single or multiple events along with the other aquatic members of the fauna and a few terrestrial erratics. Most of the aquatic individuals are represented by articulated skeletons suggesting rapid burial in quiet, perhaps anoxic conditions.

A character analysis of the Nectridea conducted by Milner 1980 recovered a monophyletic clade supported by characters of the membrane bone vertebrae but not cranial characters and a monophyletic urocordylid clade as outgroup to Scincosaurus as the sister taxon to the diplocaulids. The diplocaulid taxa formed a nested set with Keraterpeton as the most primitive taxon. The remaining taxa were structured as Batrachiderpeton, Diceratosaurus, Peronedon, Diploceraspis, Diplocaulus. Characters shared by Batrachiderpeton and Diceratosaurus, the maxilla bordering orbit margin separating the lacrimal and jugal and emarginated midline postparietal borders were cited as derived with respect to Keraterpeton. However, the emargination of the postparietal borders in Batrachiderpeton is an apomorphic feature related the presence of postparietal horns (Bossy \& Milner 1998, figs 57b, 58b). It is a very variable feature in Diceratosaurus (Bossy \& 
Milner 1998, figs 57c and pers. obs.) and not a reliable character state for this taxon. Peronedon primus Olson 1970 was redescribed and reduced to Diplocaulus primus (Olson) by Milner 1996 and falls within the generic OTU for Diplocaulus.

Relatively few cladistic analyses of early tetrapods have incorporated data on nectrideans. A detailed morphological review of the Moscovian terrestrial scincosaurid nectridean Scinosaurus by Milner \& Ruta 2009 included a critical review of large scale investigations of early tetrapods by Anderson (2001, 2007), Ruta et al. (2003) and Ruta and Coates (2007). Their data matrix of 173 characters (109 cranial and 64 postcranial) recovered a monophyletic nectridean clade and a pattern of relationships within the diplocaulid clade in agreement with Milner 1980. A revaluation of the Moroccan Late Permian Diplocaulus mimimus Dutoit, 1988 by Germain 2010 employed 45 cranial and four postcranial characters to investigate internal nectridea relationships. He found a topology that grouped Diceratosaurus with Batrachiderpeton and the long horned diplocaulids, supported by the participation of the maxilla in the lateral orbit margin. The node grouping

Batrachiderpeton as the sister taxon of the long horned genera included Peronedon as a separate OTU and was supported by the naris opening anterior to the nasal (but see preceding pargraph). However, the nasal reaches the posteromedial border of the naris in Keraterpeton and Diceratosaurus and is a primitive character for diplocaulids.

As a result of the revised diagnosis presented herein Keraterpeton and Diceratosaurus share three cranial and three postcranial primitive characters. The exposure of the postorbital occupying the posterior margin of orbit, proximal caudal vertebrae with haemal arches inserted along full length of centrum and overlapping haemal spines are synapomorphies that place Batrachiderpeton crownwards, thus reversing the order of taxa thus: Keraterpeton, Diceratosaurus, Batrachiderpeton. This agrees with the topology in Germian 2010 although that was based on a primitive diplocaulid character (see above paragraph).

The outgroup to nectrideans was found to be a node comprising three representative aiistopod taxa in Milner \& Ruta's 2009 analysis. A detailed study of the neurocranial anatomy of the earliest (Viséan) aiistopod, Lethiscus stocki, by Pardo et al. 2017 demonstrated a very primitive cranial morphology and a braincase organisation consistent with Devonian stem tetrapods, rather than with other 'lepospondyl' groups, and placed aiistopods as a stem tetrapod group. Those authors did not include nectrideans in their analysis but on the basis of their results it appears unlikely that they have any close relationship to aiistopods as found by Milner \& Ruta 2009.

The derived and specialised nature of nectrideans at their first appearance in the fossil record implies an as yet undiscovered lineage extending back to the earliest Carboniferous. A new analysis, beyond the scope of this paper, is clearly needed incorporating data from large scale tetrapod phylogenies to test the interelationships of nectrideans among early tetrapod groups (Milner \& Ruta 2009). In addition, the newly defined primitive characters of diplocaulids represented by Keraterpeton, provide data to test the monophyly of the nectridean clade. The skull morphology of urocordylids reflects adaptations to feeding mechanisms involving a mobile kinetic skull table and snout that radically different to the akinetic skull organisation diplocaulids (Bossy \& Milner 1998, Milner 1980). A separate analysis restricted to skull characters alone would prove an interesting exercise in this regard.

\section{ACKNOWLEDGEMENTS}

I dedicate this paper to my long-time friend and colleague Jenny Clack in honour of her dedicated and ground-breaking work that has revolutionised our understanding of early tetrapods. 
I am indebted to the following colleagues for access to collections and loan of material under their care: Mahala Andrews ${ }^{\dagger}, \mathrm{NMS}$; Colin Forbes ${ }^{\dagger}$, CAMSM; Mike Howe, BGS; Hugh Ivmy-Cook ${ }^{\dagger}$, BGS; Nigel Monaghan, NMI; Daniel Pemberton, CAMSM; John Playle, WARMS; Barrie Rickards ${ }^{\dagger}$, CAMSM; Chuck Schaff ${ }^{\dagger}$, MCZ; Patrick Wyse Jackson, TCD. I also thank especially Nigel Monaghan and Patrick Wyse Jackson for providing catalogue details of the Jarrow material. Nigel Monaghan also provided images of the holotype of K. galvani; Phil Crabb and Phil Hurst (Natural History Museum Image Resources) photographed NHMUK and selected NMI/TCD specimens. Lastly, I am very grateful to my husband, Andrew Milner for his help and advice and comments on the draft manuscript.

\section{REFERENCES}

Anderson, J. S. 2001. The phylogenetic trunk: maximal inclusion of taxa with missing data in an analysis of the Lepospondyli (Vertebrata, Tetrapoda). Systematic Biology 50, 170 193.

Anderson, J. S. 2007. Incorporating ontogeny into the matrix: a phylogenetic evaluation of developmental evidence for the origin of modern amphibians. 182 - 227. In Anderson, J. S. and Sues, H.-D. (eds). Major transitions in vertebrate evolution, 417 pp. Indiana University Press, Bloomington.

Andrews, C. W. 1895. Notes on a specimen of Keraterpetum galvani Huxley from Staffordshire. Geological Magazine (4) 2, 81-84.

Baily, W. H. 1881. Remarks on the fossils. In Hardman, E.T 1881, Explanatory memoir on the geology of the Leinster Coalfields, 23-26. Memoirs of the Geological Survey of the United Kingdom. Stationery Office, London.

Bossy, K. V. H. 1976. Morphology, paleoecology and evolutionary relationships of the Pennsylvanian urocordylid nectrideans (Subclass, Lepospondyli, Class Amphibia). Dissertation Abstracts (B) 37, 2731.

Bossy, K. A. \& Milner, A. C. 1998. Order Nectridea. In Carroll, R. L. Bossy, K. A., Milner, A. C., Andrews, S. M. \& Wellstead, C. F. 1998. Handbuch der Paläoherpetologie. Teil 1, Lepospondyli, 73-132. Dr Friedrich Pfeil, München.

Brownrigg, W. B. 1865. Notes on part of the Leinster Coalfield, with a record of some fossils found therein. Dublin Quarterly Journal of Science 6, 195-196.

Carroll, R. L., Bossy, K. A., Milner, A. C., Andrews, S. M. \& Wellstead, C. F. 1998. Handbuch der Paläoherpetologie. Teil 1, Lepospondyli, 216 pp. Dr Friedrich Pfeil, München.

Carroll, R. L. 1989. Developmental aspects of lepospondyl vertebrae in Paleozoic tetrapods. Historical Biology 3, 1-25.

Chaney, D. S., Sues, H. - D. \& DiMichele, W. A. 2005. A juvenile skeleton of the nectrideanamphibian Diplocalus and associated flora and fauna form the Mitchell Creek Flats locality (Upper Waggoner Ranch Formation; Early Permian), Baylor County, North Central Texas, USA. 39-47. In Lucas, S. G. \& Zeiger, K. E. 2005. The Nonmarine Permian. Bulletin of the New Mexico Museum of Natural History 6, 1 362.

Commission of Inquiry. 1921. Memoir on the Coalfields of Ireland, 396 pp. Cahill, Dublin, Cope, E. D. 1875. Synopsis of the extinct Batrachia from the Coal Measures. Report of the Geological Survey of Ohio, Volume 2 (2) Paleontology, 351- 411. Columbus.

DeArce, M., Monaghan, N. T. \& Wyse Jackson, P. N. 2011. The uneasy correspondence between T. H. Huxley and E. P. Wright on fossil vertebrate found in Jarrow Co. 
Kilkenny (1865-67). Notes and Records of the Royal Society 63, 253- 271. doi: $10.1098 /$ rsnr.2010.0081

Dix, E. 1931. Flora of the Upper portion of the Coal Measures of North Staffordshire. Quarterly Journal of the Geological Society of London 87, 160-179.

Dutuit J-M. 1988. Diplocaulus minimus n. sp. (Amphibia: Nectridea), lépospondyle de la formation d'Argana, dans l'Atlas occidental marocain. Compte rendu de l' Academie des Sciences, Paris Série II 307, 851-854.

Eagar, R. M. C. 1961. A note on the non-marine lamellibranchs of the Leinster, Slieveard and Kanturk Coalfields. 11- 15. In Nevill, W. E. 1961. The Millstone grit and Lower Coal Measures of the Leinster Coalfield. Proceedings of the Royal Irish Academy (B) 8, 1-15.

Eagar, R. M. C. 1964. The succession and correlation of the Coal Measures of South Eastern Ireland. Compte rendu de la Cinquième Congrès our l'avancement des études de stratigraphie et de géologie du carbonifère 7, 359-374. International Subcomission on Carboniferous Stratigraphy. Paris.

Etheridge, R. 1866. On the discovery of several new Labyrinthodont Reptiles in the Coal Measures of Ireland, Geological Magazine 3, 4-5.

Germian, D. 2010. The Moroccan diplocaulid: the last lepospondyl, the single one on Gondwana. Historical Biology 22, 4-39.

Gibson, W., Barrow, G., Wedd, C. B. \& Ward, J. 1905. Geology of the North Staffordshire Coalfields, 522pp. Memoirs of the Geological Survey of the United Kingdom. Stationery Office, London.

Hallissy, T. 1939. The geology of S. E. Ireland. iv, The Coalfields of S.E. Ireland, Proceedings of the geologists' Association 50, 330-334.

Higgs, K. T. \& O'Connor, G. 2005. Stratigraphy and palynology of the Westphalian strata of the Leinster Coalfield, Ireland. Irish Journal of Earth Sciences 23, 65-84.

Huxley, T. H. \& Wright, E. P. 1867. On a collection of fossil Vertebrates from the Jarrow Colliery, County of Kilkenny, Ireland. Transactions of the Royal Irish Academy 24, 351-368.

Jaekel, O. 1903. Ueber Ceraterpeton, Diceratosaurus u Diplocaulus. Neues Jahrbuch für Mineralogie, Geologie und Paläontologie 1, 109-134

Kendall, P. F. 1923. The physiography of the coal swamps. Report of the $90^{\text {th }}$ Meeting of the British Association for the Advancement of Science 1922, 49-78.

Lydekker, R. 1890. Catalogue of the fossil Reptiles and Amphibians in the British Museum (Natural History), Part IV. London, British Museum (Natural History).

Miall, L.C. 1875. Report of the committee on the structure and classification of the labyrinthodonts. Report of the $44^{\text {th }}$ Meeting of the British Association for the Advancement of Science 1874, 149-192.

Milner, A. C. 1978. Carboniferous Keraterpetontidae and Scincosauridae (Nectridea: Amphibia) - a review. Unpublished $\mathrm{PhD}$ thesis, University of Newcastle upon Tyne $192 \mathrm{pp}$.

Milner, A. C. 1980. A review of the Nectridea (Amphibia). In Panchen, A. L. (ed.) The terrestrial environment and the origin of vertebrates, 377- 405. Systematics Association Special Volume No. 15 Academic Press, London.

Milner, A.C. 1996. A juvenile long-horned nectridean (Amphibia) from the Lower Permian of the southeastern USA and the status of the family Diplocaulidae. Special Papers in Palaeontology, 52, 29-38.

Milner, A. C. 1998. Diplocaulidae Cope 1881. In Carroll, R. L., Bossy, K. A., Milner, A. C., Andrews, S. M. \& Wellstead, C. F. 1998. Handbuch der Paläoherpetologie. Teil 1, Lepospondyli, 121-131. Dr Friedrich Pfeil, München. 
Milner, A. C. \& Ruta, M. 2009. A revision of Scincosaurus (Tetrapoda, Nectridea) from the Moscovian of Nýrany, Czech Republic, and the phylogeny and interrelationships of nectrideans. Special Papers in Palaeontology 81,71-89.

Milner, A. R. 1980. The temnospondyl amphibian Dendrerpeton from the Upper Carbonifeous of Ireland. Palaeontology 23,125-141.

Nevill, D. E. 1961. The Westphalian of Ireland. Compte rendu de la 4ème Congrès pour l'avancement des études de stratigraphie et de géologie du carbonifère 2, 453460.

Newberry, J. S. 1867. On some fossil reptiles and fished from the coal strata of Ohio, Kentucky and Illinois. Proceedings of the American Association for the Advancement of Science 1867, 144-146.

Oldham, T. B. 1876. On a salamandriform Labyrinthodon (Keratespeton? sp.) from the Coal Measures near Castlecomer, Ireland. Report of the Rugby School Natural History Society 1875, 74-76.

Milner, A. C. 1996. A juvenile long-horned nectridean (Amphibia) from the Lower Permian of the southeastern USA and the status of the family Diplocaulidae. Special Papers in Palaeontology, 52, 29-38.

Pardo, J. D., Szostakwiskji, M., Ahlberg, P. E. \& Anderson, J. S. 2017. Hidden morphological diversity among early tetrapods. Nature 564, 642-645.

Rayner, D. H. 1971. Date on the environment and preservation of Late Palaeozoic tetrapods, Proceedings of the Yorkshire Geological Society 38, 437-495.

Rees, J. G. \& Wilson, A. A. 1998. Geology of the country around Stoke-on-Trent: memoir for 1:50 000 geological sheet 123 (England and Wales). British Geological Survey Natural Environment Research Council (Great Britain). 152 pp. London, Stationary Office.

Romer, A. S. 1933. Vertebrate Paleontology. First Edition, 491 pp. Chicago, Chicago University Press.

Ruta, M. \& Coates, M. I. 2007. Dates, nodes and character conflict: addressing the amphibian origin problem. Journal of Systematic Palaeontology 5, 69-122.

Ruta, M. \& Coates, M. I. \& Quicke, D. L. J. 2003. Early tetrapod relationships revisited. Biological Reviews of the Cambridge Philosophical Society 78, 251-345.

Sequeira, S. E. K. 1996. A cochleosaurid amphibian from the Upper Carboniferous of Ireland. Special Papers in Palaeontology, 52, 65-80.

Stucker, G. F. 1961. Salvaging fossils by jet. Curator 4, 332-340.

Thomson, K. S. \& Bossy, K. V. H. 1970. Adaptive trends and relationships in ear Amphibia. Forma et Functio 3, 7-31.

Ward, J. 1890. The Geological features of the North Staffordshire Coal fields, their organic remains, their range and distribution, with a Catalogue of the Fossils of the Carboniferous System of North Staffordshire. Transactions of the North Staffordshire Institute of Mining and Mechanical Engineers 10,1-189.

Witzmann, F. 2013. Phylogenetic patterns of character evolution in the hyobranchial apparatus of early tetrapods. Earth and Environmental Science Transactions of the Royal Society of Edinburgh 104, 145-167.

Woodward, A. S. 1897. On a new specimen of the stegocephalan [sic] Ceraterpeton galvani Huxley from the Coal Measures of Castlecomer, Kilkenny, Ireland. Geological Magazine (4) 4, 293-298.

Wright, E. P. \& Huxley, T. H, 1866. On a collection of fossils from the Jarrow Colliery Kilkenny. Geological Magazine (3) 3, 165-171.

Wyse Jackson, P. N., DeArce, M. \& Monaghan, N. T. 2011. A letter from William Bookey Brownrigg to Thomas Henry Huxley, dated 29 November 1865, authorising him to 
describe his fossil vertebrates from Jarrow Colliery, Co. Kilkenny and giving details of his find. Irish Journal of Earth Sciences 29, 19-22. 
Figure 1 NMING F:14735 Keraterpeton galvani holotype in dorsal aspect (A) figured by Huxley and Wright 1867, pl. 19, fig. 1, (B) as now preserved showing missing hind limbs. Scale bar $=30 \mathrm{~mm}$.

Figure 2 NMS 1950.56.6 Keraterpeton galvani skeleton in ventral aspect, distal region of tail restored from Woodward 1897 (pl. 12). Scale bar $=20 \mathrm{~mm}$.

Figure 3 BGS 26842 Keraterpeton galvani skull in dorsal aspect (A) photograph, (B) interpretative drawing, $(\mathrm{C})$ reconstruction of skull in dorsal aspect, (D) reconstruction of skull in left lateral aspect. Abbreviations: $\mathrm{A}=$ articular; $\mathrm{AN}=$ angular; $\mathrm{D}=$ dentary; $\mathrm{FR}=$ frontal; $\mathrm{J}=$ jugal; $\mathrm{L}=$ lacrimal; $\mathrm{mg}=$ Meckelian groove; $\mathrm{MX}=$ maxilla; $\mathrm{N}=$ nasal; $\mathrm{PA}=$ parietal; $\mathrm{PMX}=$ premaxilla; $\mathrm{POF}=$ postfrontal; $\mathrm{PP}=$ postparietal; $\mathrm{PRF}=$ prefrontal; $\mathrm{Q}=$ quadrate; $\mathrm{QJ}$ $=$ quadratojugal; $\mathrm{RT}=$ retroarticular process; $\mathrm{SA}=$ surangular; $\mathrm{SQ}=$ squamosal; $\mathrm{T}=$ tabular. Scale bar $=10 \mathrm{~mm}$.

Figure 4 NHMUK PV R 2395 Keraterpeton longtoni skeleton in dorsal aspect (A) photograph of block comprising most of the skeleton, (B) interpretative drawing of skull and anterior postcranium. Abbreviations: $\mathrm{AT}=$ atlas; $\mathrm{CLA}=$ clavicle; $\mathrm{CLE}=$ cleithrum; $\mathrm{L}=$ lacrimal; MAND = mandible; $\mathrm{PA}=$ parietal; $\mathrm{PP}=$ postparietal; $\mathrm{QJ}=$ quadratojugal; $\mathrm{SC}=$ scapulocoracoid. Scale bar $=10 \mathrm{~mm}$.

Figure 5 CAMSM A.5969 Keraterpeton galvani skull drawing in dorsal aspect with right mandible displacing anterior end of maxilla. Abbreviations: ext. $\mathrm{n} .=$ external naris; $\mathrm{J}=$ jugal; $\mathrm{L}=$ lacrimal; $\mathrm{MAND}=$ mandible $; \mathrm{MX}=$ maxilla; $\mathrm{N}=$ nasal; $\mathrm{PMX}=$ premaxilla. Scale bar $=$ $10 \mathrm{~mm}$.

Figure 6 NHMUK PV R 2395 Keraterpeton longtoni composite outline of skull including anterior snout preserved on small counterslab partly as a mould. Abbreviations: $a c=$ anterior commissure; sos = supraorbital sulcus; tos = transverse commissure; ts = temporal sulcus. Scale bar $=10 \mathrm{~mm}$.

Figure 7 TCD R252 Keraterpeton galvani skull in ventral aspect. Dorsal aspect of the right cheek and mandible, broken along the lateral orbit margin are crushed over obscuring the mid-line region of the palate. (A) Photograph, (B) Interpretative drawing of identifiable structures. Abbreviations: $\mathrm{A}=$ articular; $\mathrm{AN}=$ angular; $\mathrm{D}=$ dentary; $\mathrm{MX}=$ maxilla; $\mathrm{N}=$ nasal; $\mathrm{PA}=$ parietal; $\mathrm{PAL}=$ palatine; $\mathrm{PMX}=$ premaxilla; $\mathrm{PT}=$ ptergoid; $\mathrm{Q}=$ quadrate; $\mathrm{SA}=$ surangular; $\mathrm{SQ}=$ squamosal; $\mathrm{T}=$ tabular; $\mathrm{V}=$ vomer. Scale bar $=10 \mathrm{~mm}$.

Figure 8 MCZ 2193 Keraterpeton galvani photograph of skull in ventral aspect. Abbreviations: $\mathrm{B}=$ basibranchial; $\mathrm{BOC}=$ basioccipital; $\mathrm{b} . \mathrm{pr}=$ basipterygoid process; $\mathrm{EO}=$ exoccipital; $\mathrm{EOC}=$ exoccipital condyle; ipt.v = interpterygoid vacuity; $\mathrm{OP}=$ opisthotic; $\mathrm{PAL}$ $=$ palatine $; \mathrm{PMX}=$ premaxilla; $\mathrm{PSP}=$ parasphenoid $\mathrm{PT}=$ pterygoid $; \mathrm{Q}=$ quadrate; $\mathrm{QJ}=$ quadratojugal; $\mathrm{V}=$ vomer. Scale bar $=10 \mathrm{~mm}$.

Figure 9 Reconstruction of the palate based on Figs 7 and 8. Abbreviations: $\mathrm{BOC}=$ basioccipital; b.pr = basipterygoid process; $\mathrm{EO}=$ exoccipital; $\mathrm{EOC}=$ exoccipital condyle; ipt.v = interpterygoid vacuity; $\mathrm{MX}=$ maxilla; $\mathrm{OP}=$ opisthotic; $\mathrm{PAL}=$ palatine $; \mathrm{PMX}=$ premaxilla; $\mathrm{PSP}=$ parasphenoid; $\mathrm{PT}=$ pterygoid; $\mathrm{SQ}=$ squamosal; $\mathrm{Q}=$ quadrate; $\mathrm{QJ}=$ quadratojugal; $\mathrm{V}=$ vomer. Scale bar $=10 \mathrm{~mm}$. 
Figure 10 MCZ 2193 Keraterpeton galvani interpretative drawing of basibranchial from Fig. 7. Scale bar $=5 \mathrm{~mm}$.

Figure 11 CAMSM A.5969 Keraterpeton galvani skeleton (A) skull in dorsal aspect with vertebral column in left lateral aspect. Scale bar $=10 \mathrm{~mm}$. (B) Interpretative drawings of proximal presacrals 5 and 6 , distal presacrals 13 and 14. Abbreviations: $\mathrm{CAP}=$ capitulum; $\mathrm{HA}=$ haemal arch; TUB - tuberculum; NA = neural arch; TP = transverse process; za = prezyapophysis; $\mathrm{zp}=$ postzyapophysis; zyga $=$ zygantrum; $\mathrm{zygp}=$ zygosphene

Scale bar $=5 \mathrm{~mm}$.

Figure 12 CAMSM E.19871 Keraterpeton galvani interpretative drawing of mid-caudal vertebrae in. Abbreviations: $\mathrm{HA}=$ haemal spine; $\mathrm{NS}=$ neural spine; $\mathrm{za}=$ prezyapophysis; $\mathrm{zp}$ $=$ postzyapophysis. Scale bar $=5 \mathrm{~mm}$.

Figure 13 NHMUK PV R 8452 Keraterpeton galvani skeleton in dorsal aspect (A) photograph (B) interpretive drawing. Abbreviations: $\mathrm{CR}=$ caudal rib; $\mathrm{HS}=$ haemal spine; $\mathrm{SR}=$ sacral rib. Scale bar $=10 \mathrm{~mm}$.

Figure 14 NMING F14711 Keraterpeton galvani interpretative drawing of sacral region. Abreviations: $\mathrm{CR}=$ caudal rib; $\mathrm{IL}=$ ilium; $\mathrm{SR}=$ sacral rib. Scale bar $=10 \mathrm{~mm}$.

Figure 15 BGS 26842 Keraterpeton galvani interpretative drawing of pectoral girdle and associated forelimb elements in ventral aspect. Abreviations: CLA = clavicle; DS $=$ dorsal scale; $\mathrm{ICL}=$ interclavicle; $\mathrm{H}=$ humerus, $\mathrm{R}=$ rib; $\mathrm{RA}=$ radius; $\mathrm{U}=$ ulna. Scale bar $=10 \mathrm{~mm}$.

Figure 16 NMING F14696 Keraterpeton galvani photograph of skull and and anterior region of trunk in left lateral aspect. Abreviations: $\mathrm{CLA}=$ clavicle; $\mathrm{CLE}=$ cleithrum; $\mathrm{ED}=$ extra dermal ossification; $\mathrm{ICL}=$ interclavicle; $\mathrm{SC}=$ scapulocoracoid. Scale bar $=10 \mathrm{~mm}$.

Figure 17 TCD R252 Keraterpeton galvani interpretative drawing of right forelimb in medial and ventral aspects. Abreviations: $\mathrm{CL}=$ clavicle; $\mathrm{CLE}=$ cleithrum; $\mathrm{COR}=$ coracoid; end = endepicondyle; ent = entepicondyel; $\mathrm{gl}=$ glenoid; $\mathrm{H}=$ humerus; $\mathrm{RA}=$ radius; $\mathrm{SC}=$ scapula; supc.f $=$ supracoracoid foramen; $U=$ ulna. Scale bar $=5 \mathrm{~mm}$.

Figure 18 MCZ 2193 Keraterpeton galvani interpretative drawing right of left forelimb in ventral aspect. Abreviations: $\mathrm{H}=$ humerus; $\mathrm{RA}=$ radius; $\mathrm{T}=$ tabular; $\mathbf{U}=\mathrm{ulna}$; $\mathrm{I}=$ digit one; $\mathrm{II}=$ digit two; III = digit 3; IV = digit four; $\mathrm{V}=$ digit five. Scale $\mathrm{bar}=5 \mathrm{~mm}$.

Figure 19 NMING F14696 Keraterpeton galvani interpretative drawing of right sacral region in ventral aspect. Abreviations: $\mathrm{CR}=$ caudal rib; $\mathrm{IL}=$ ilium; $\mathrm{SR}=$ sacral rib. Scale bar $=10$ $\mathrm{mm}$.

Figure 20 TCD R252 Keraterpeton galvani interpretative drawing of hind limb. Abreviations: $\mathrm{CR}=$ caudal rib; $\mathrm{FE}=$ femur; $\mathrm{FB}=$ fibula; $\mathrm{SV}=$ sacral vertebra; $\mathrm{TB}=$ tibia. Scale bar $=10 \mathrm{~mm}$.

Figure 21 NHMUK PV R 8457 Keraterpeton galvani skeleton in ventral aspect with dermal scales overlying right ribs and presacral centra. Inset; close up of scales overlying right ribs. Scale bar $=10 \mathrm{~mm}$. 
Earth and Environmental Science Transactions of the Royal Society of EdiRbgeght of 43 A

B

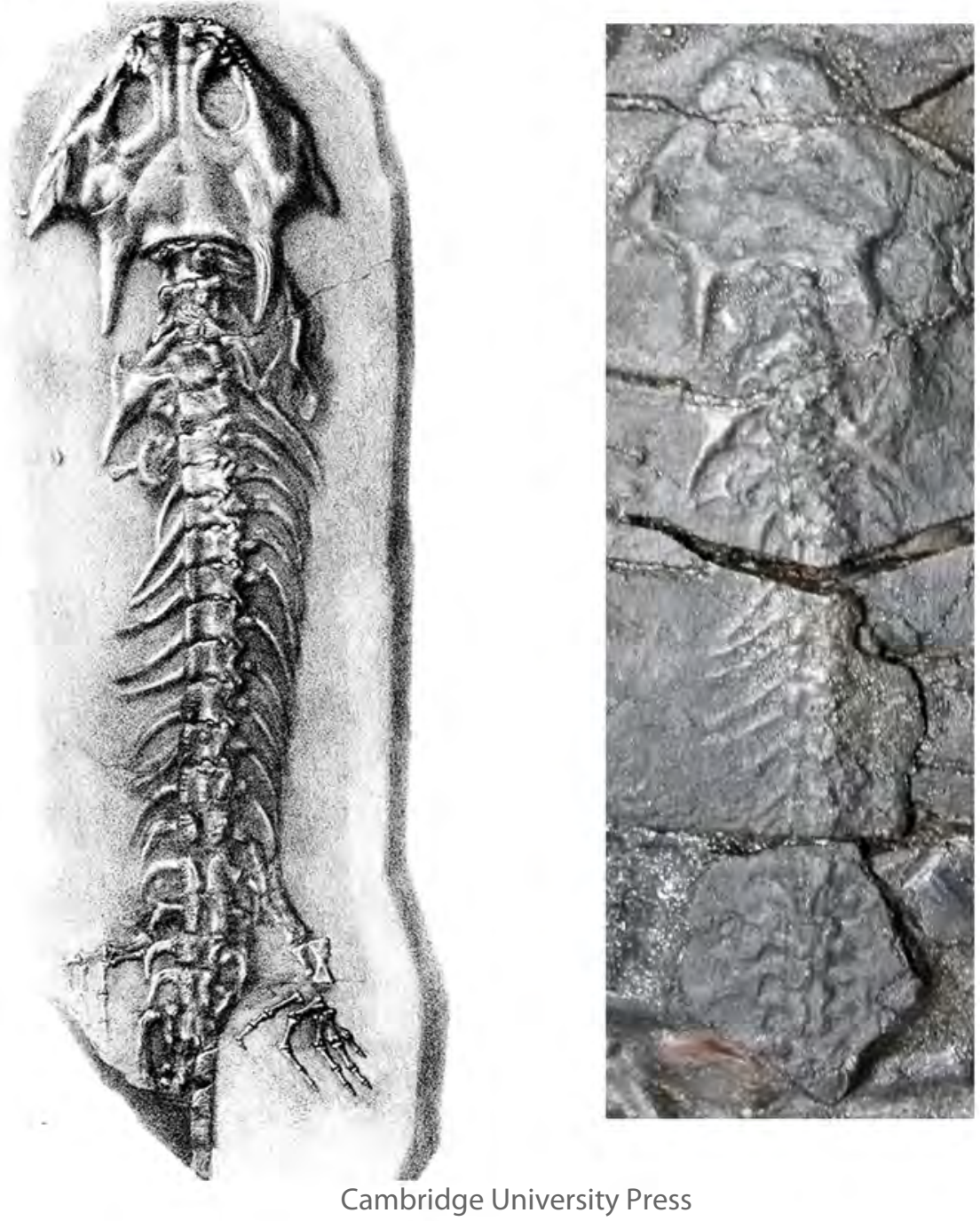


A

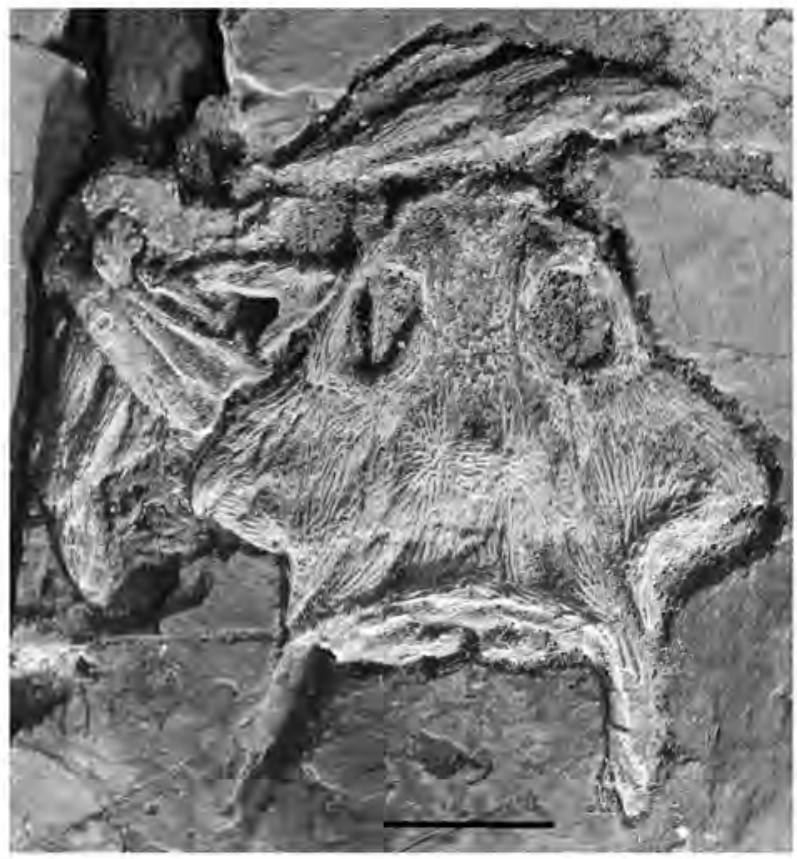

D

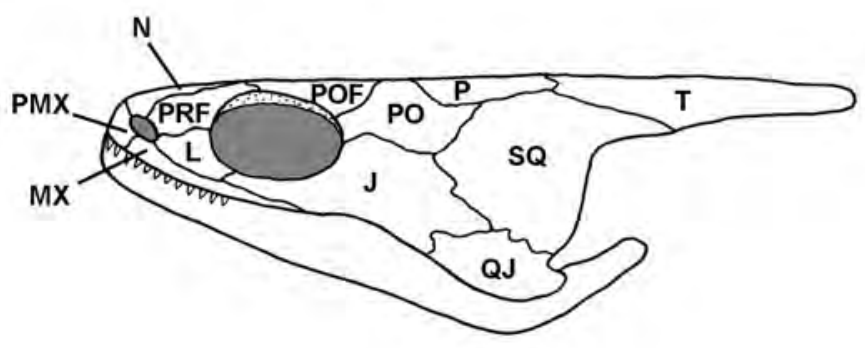

B

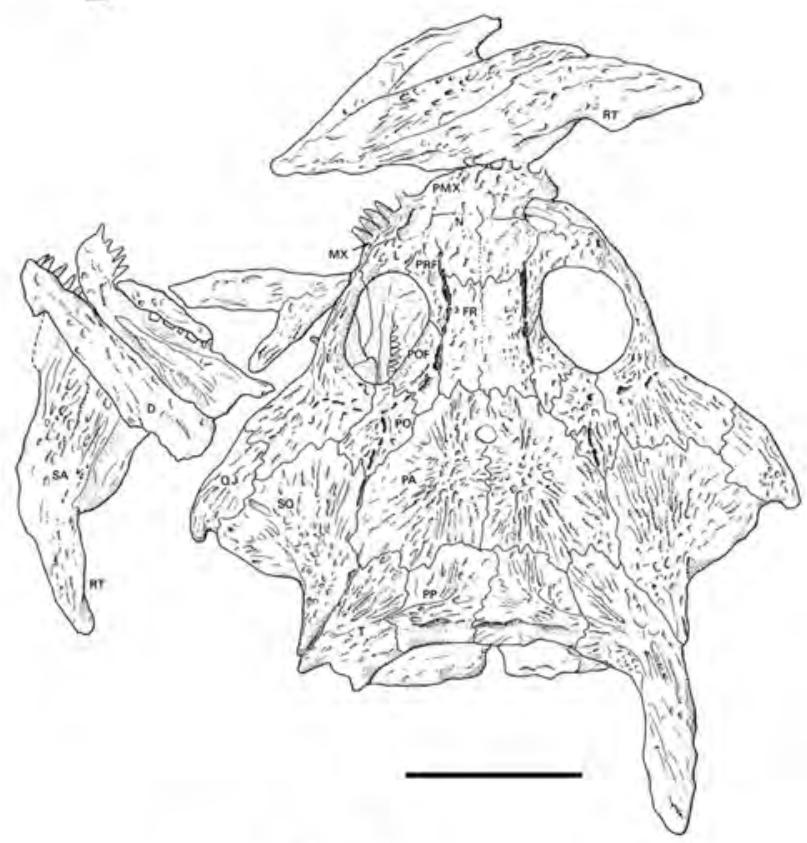

C

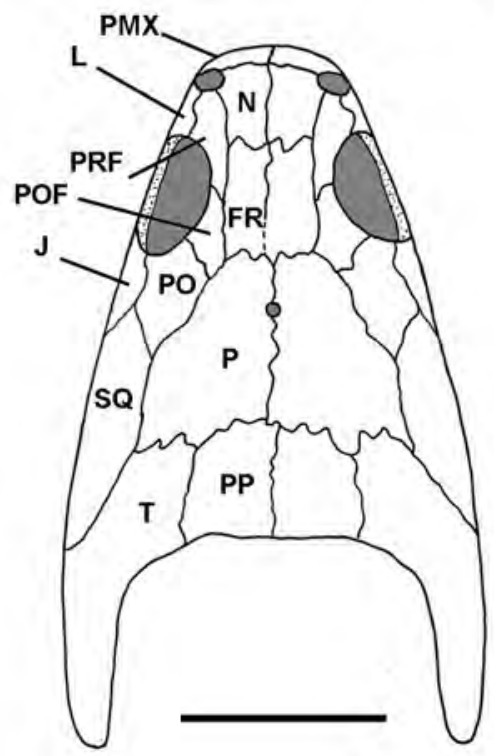



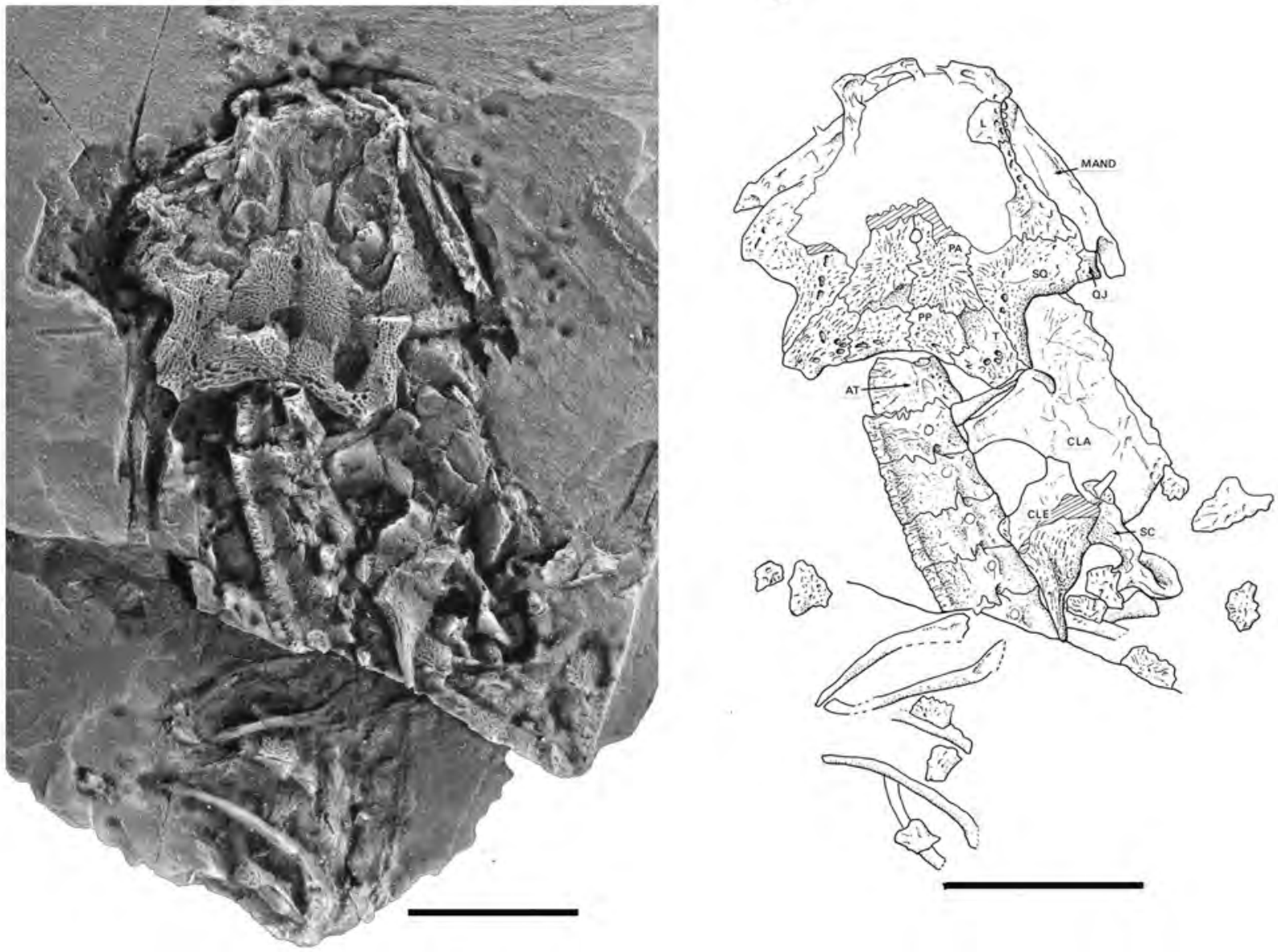
ronmental Science Transactions of thegp@\&8| SfotBet)

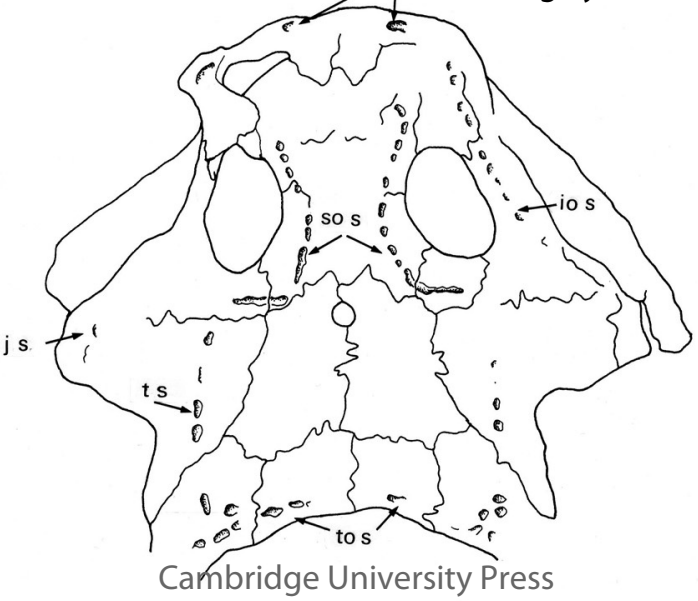


P 29 of 43 Earth and Environmental Science Transactions ofthe Royal Society of Edinburgh
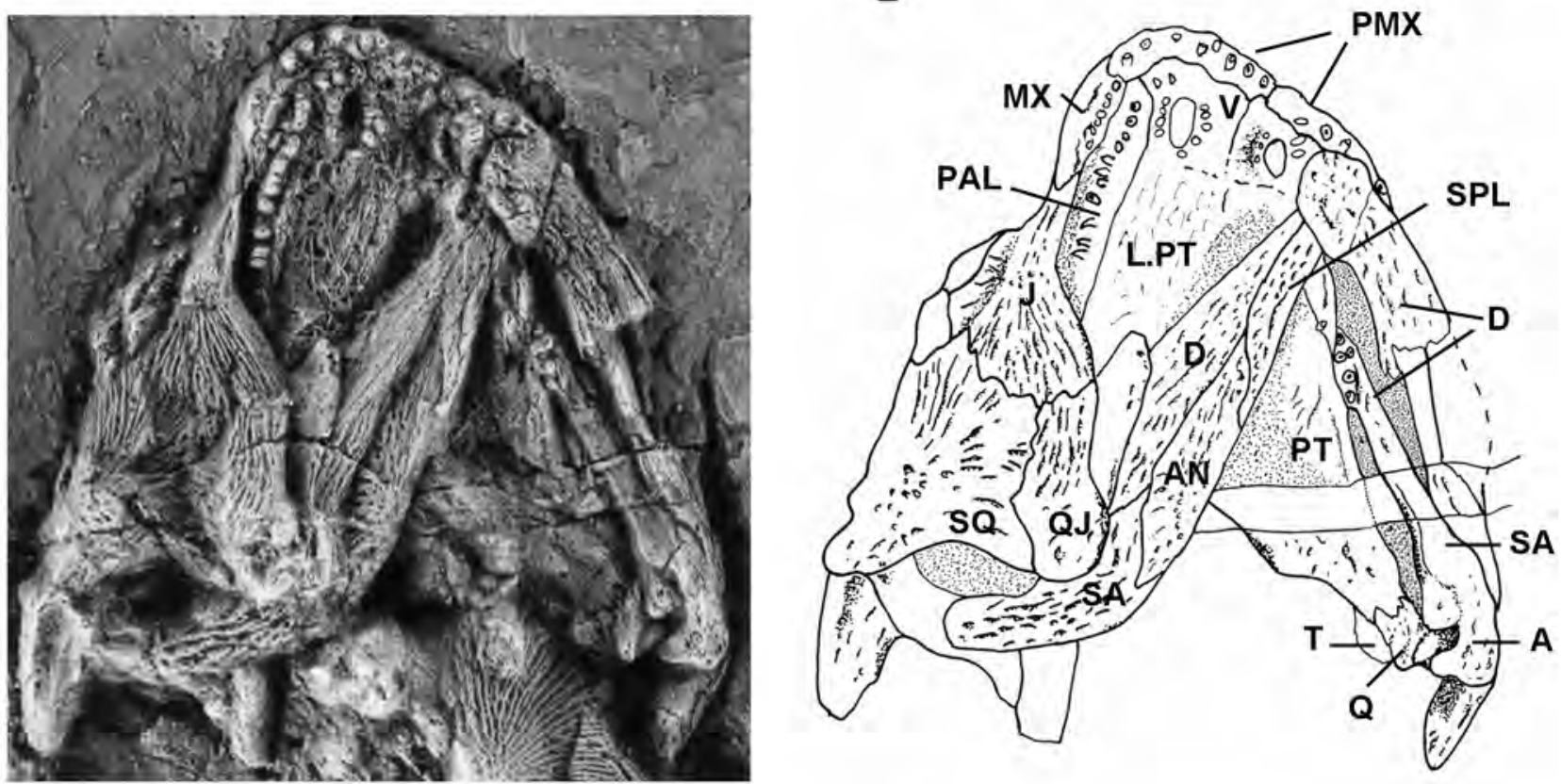


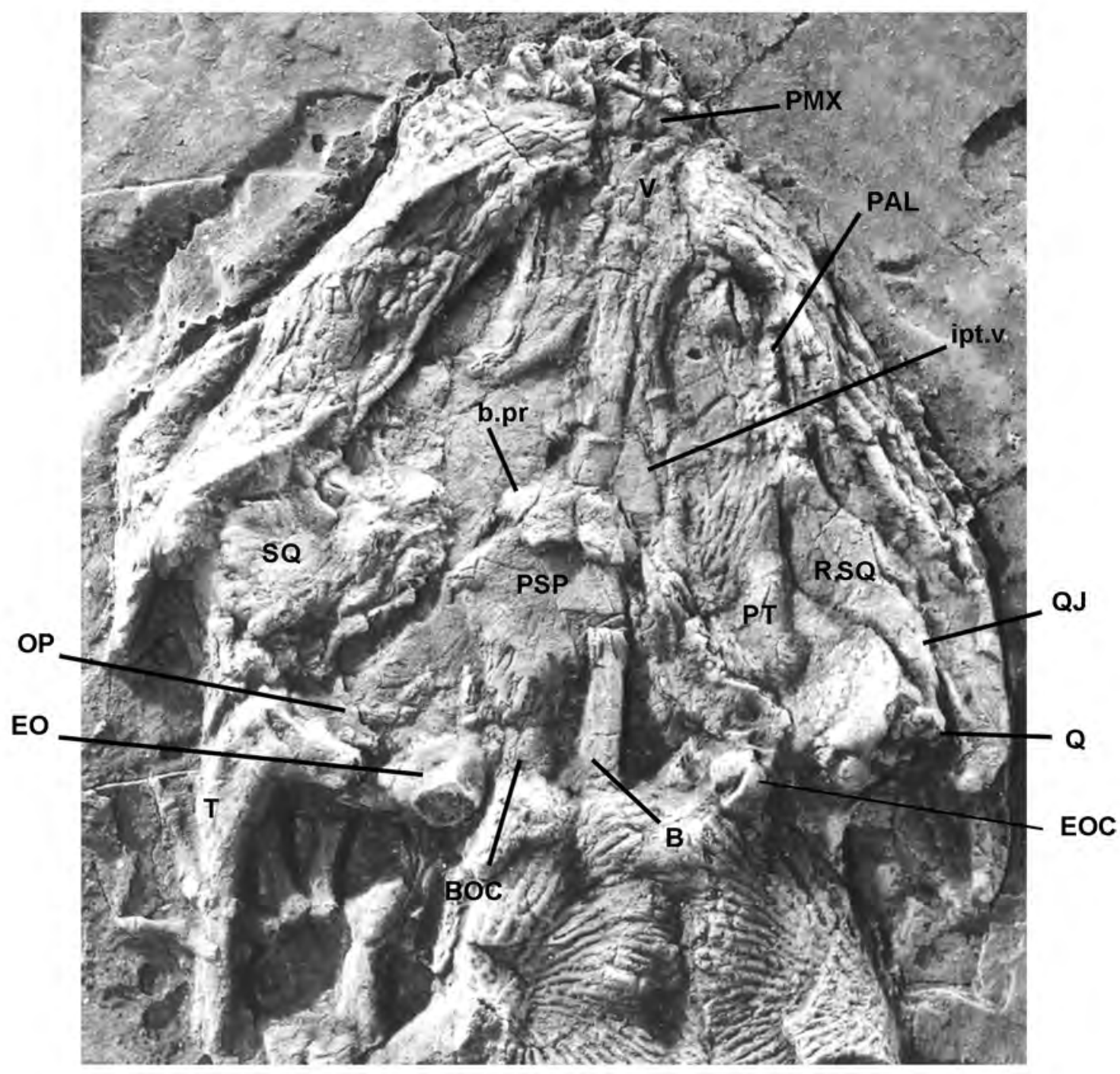

Cambridge University Press 


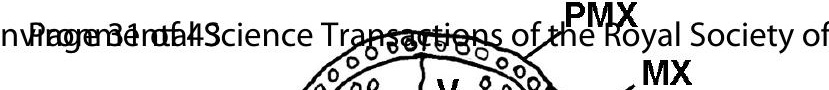

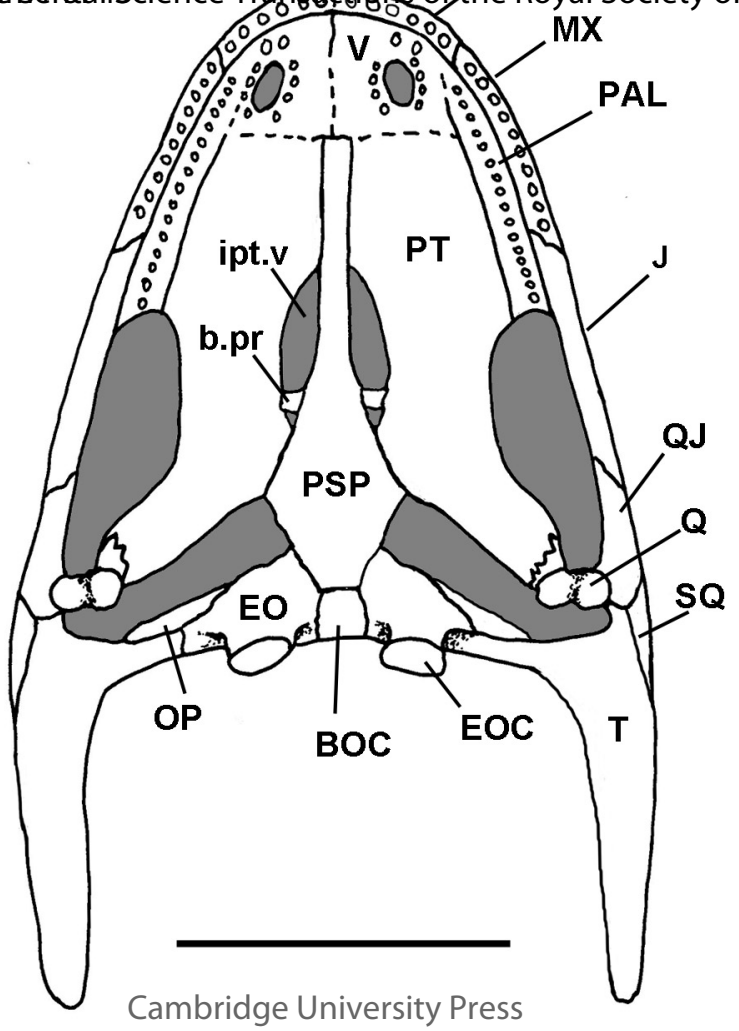




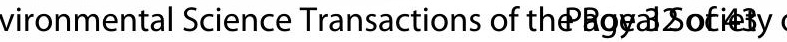

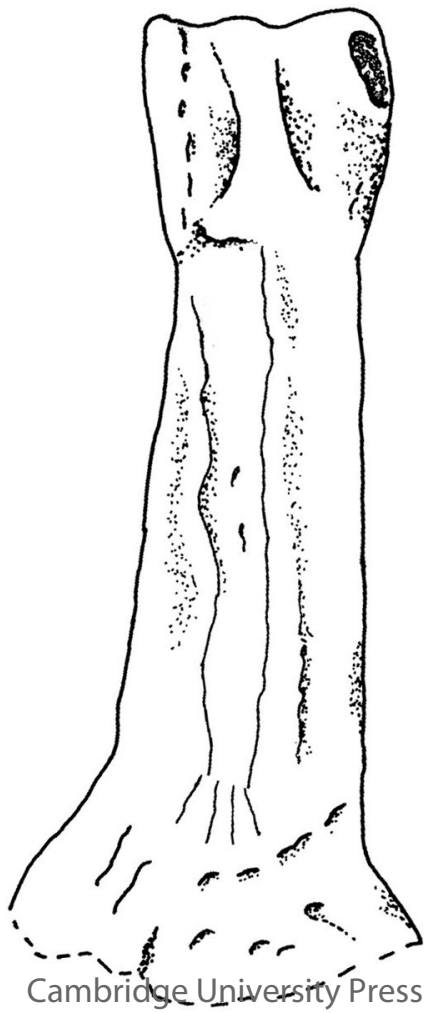




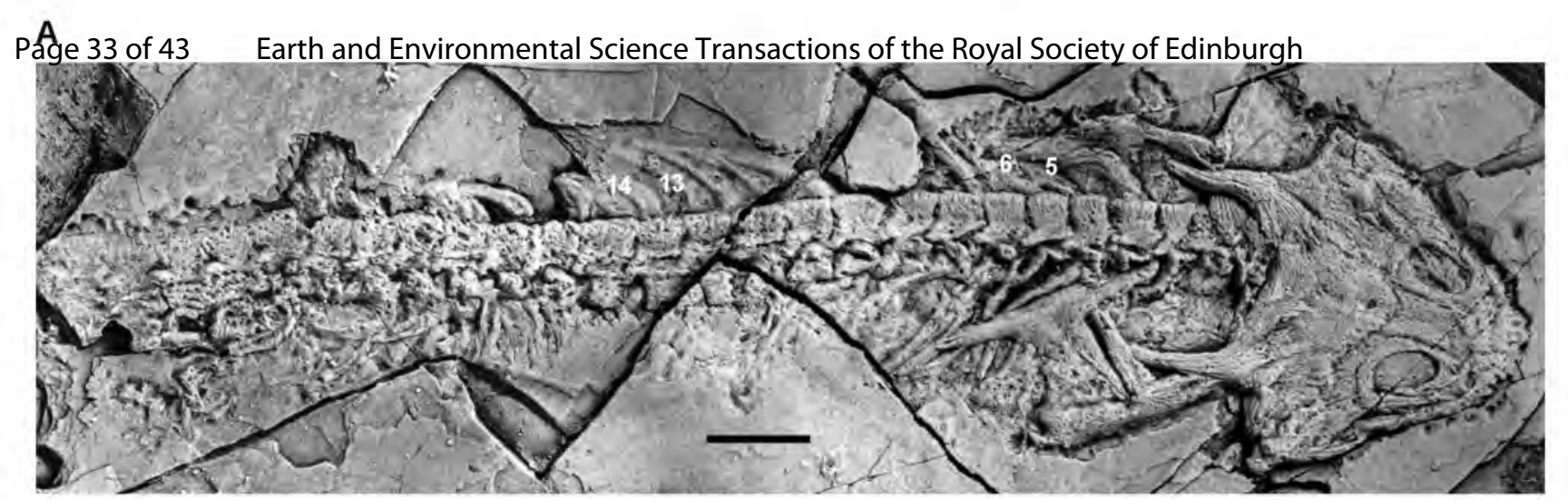

C

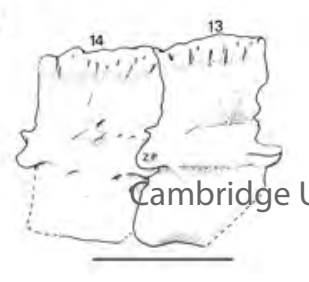

B

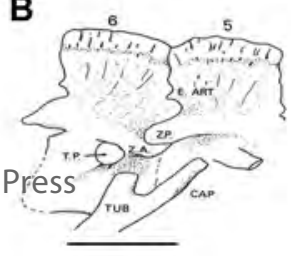




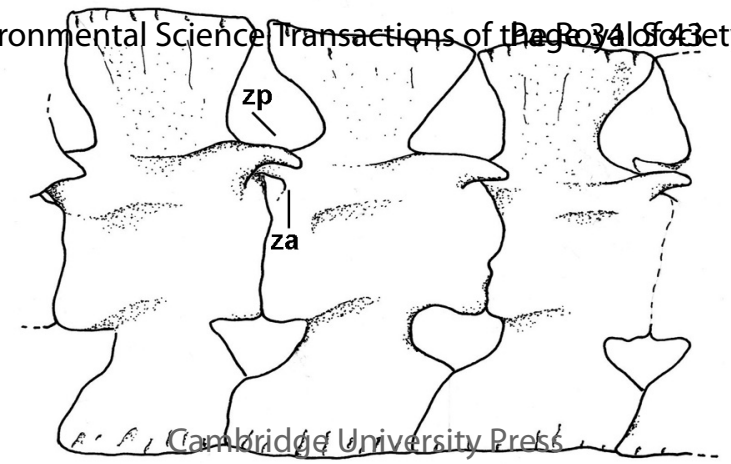




\section{A}

Page 35 of 43 Earth and Environmental Science Transactions of the Royal Society of Edinburgh

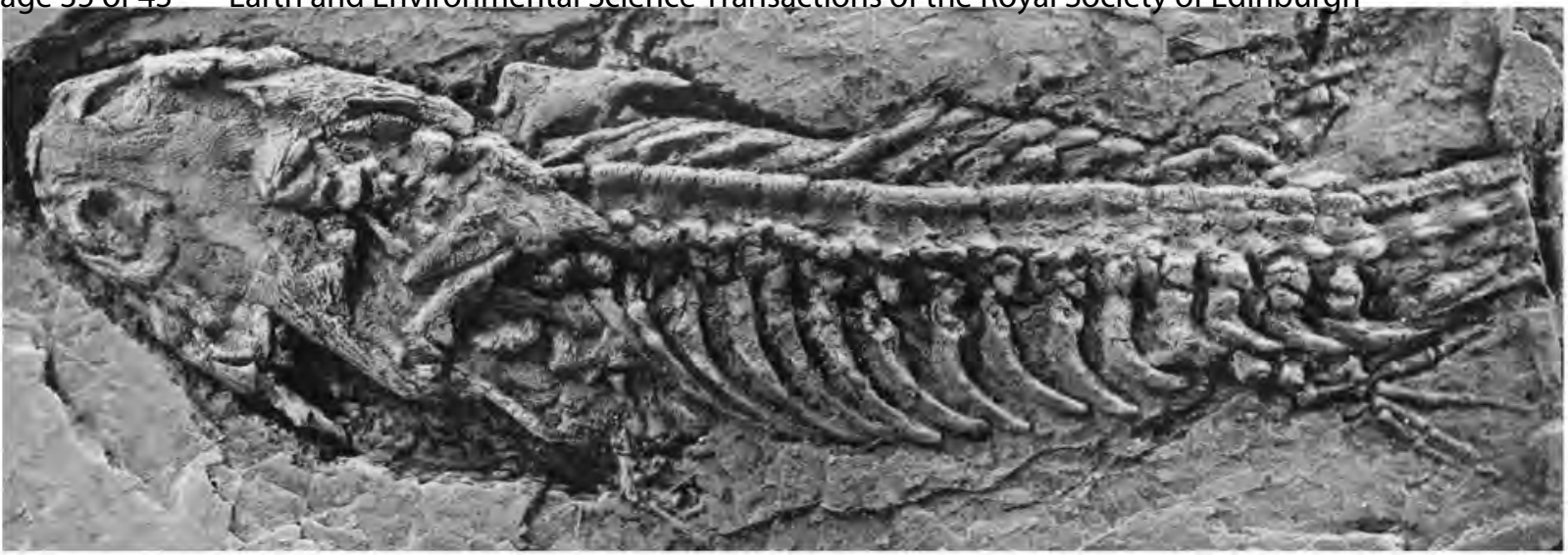

B

CLE

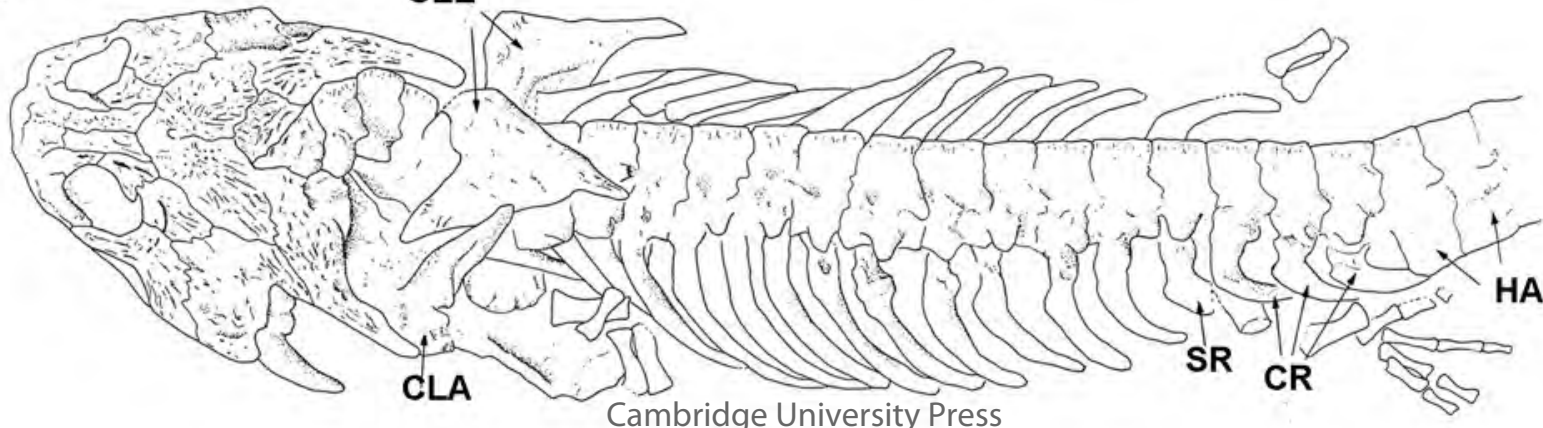

Cambridge University Press 


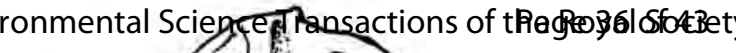

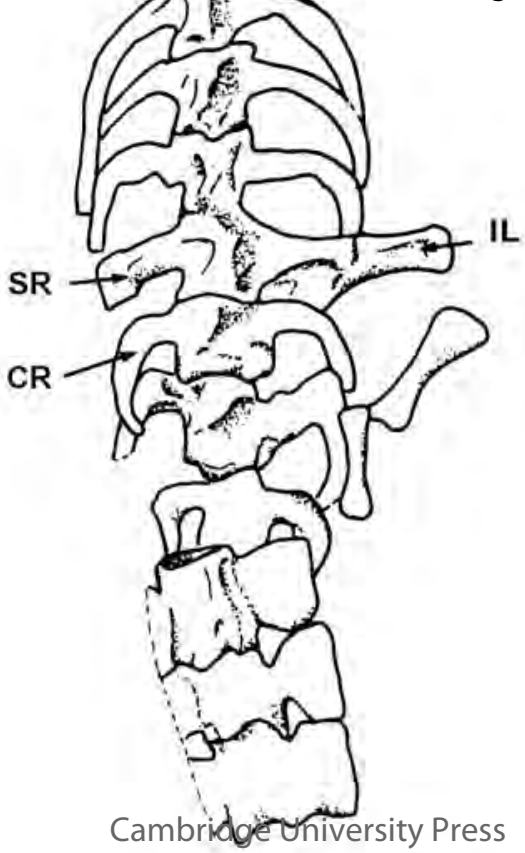


IVPegen

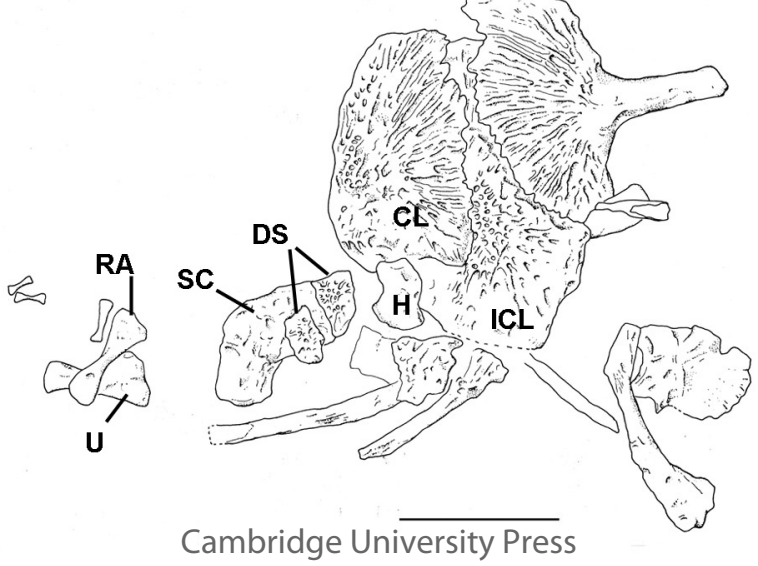


nvironmental Science Transactions of the Rage/ 38 oie 43 . of

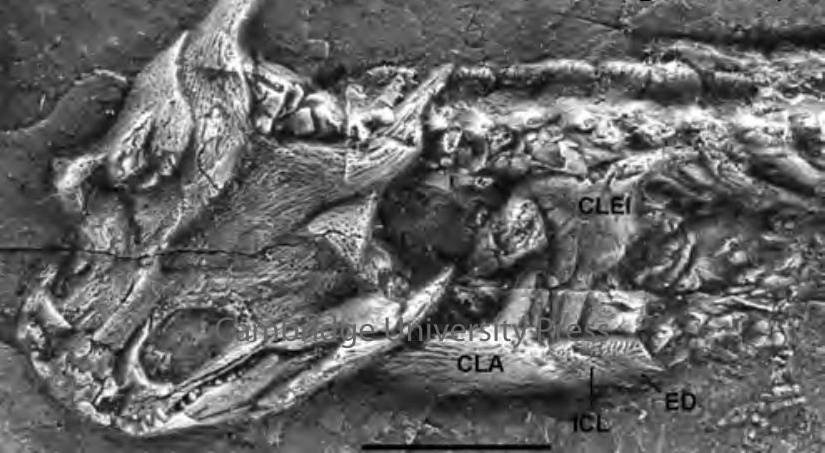




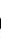

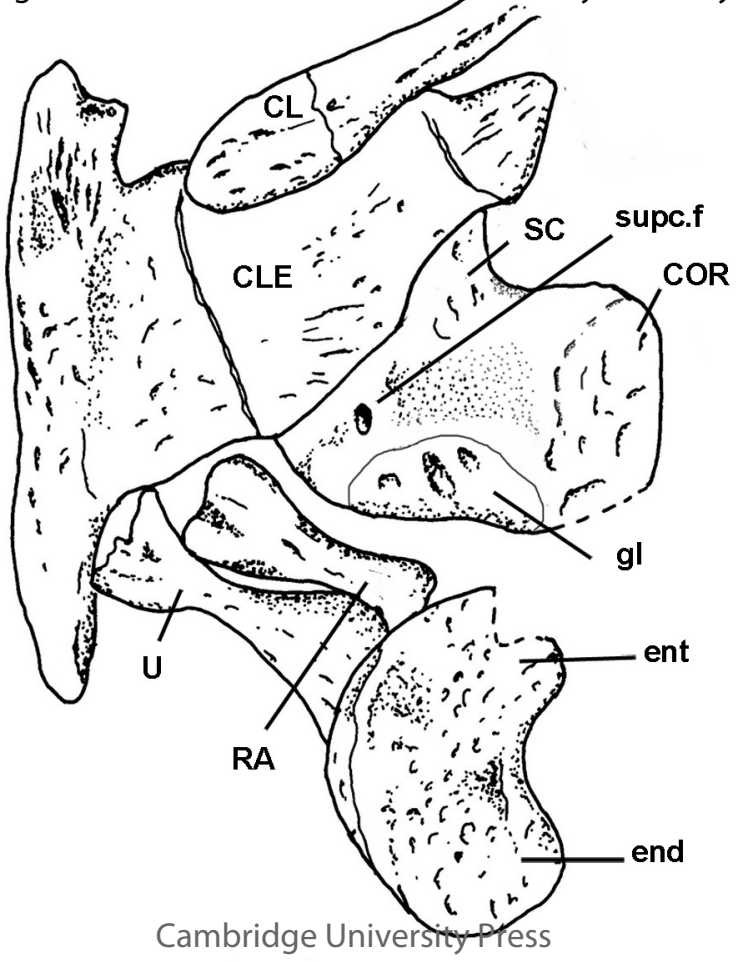


al Science TransactPange \&fotbe 4 Boy

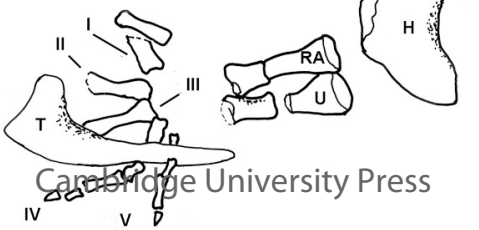


nePatge Sdierfese3Transactions of the Royal So

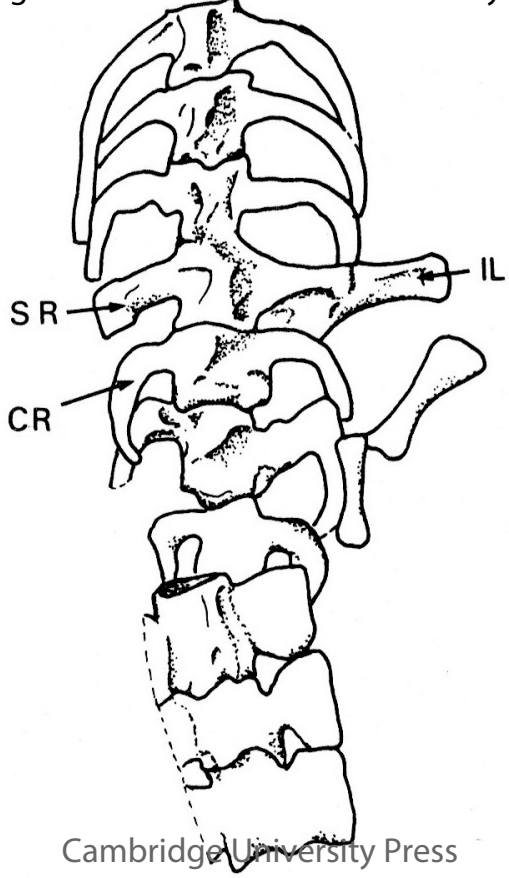




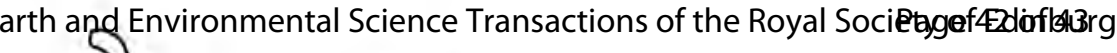

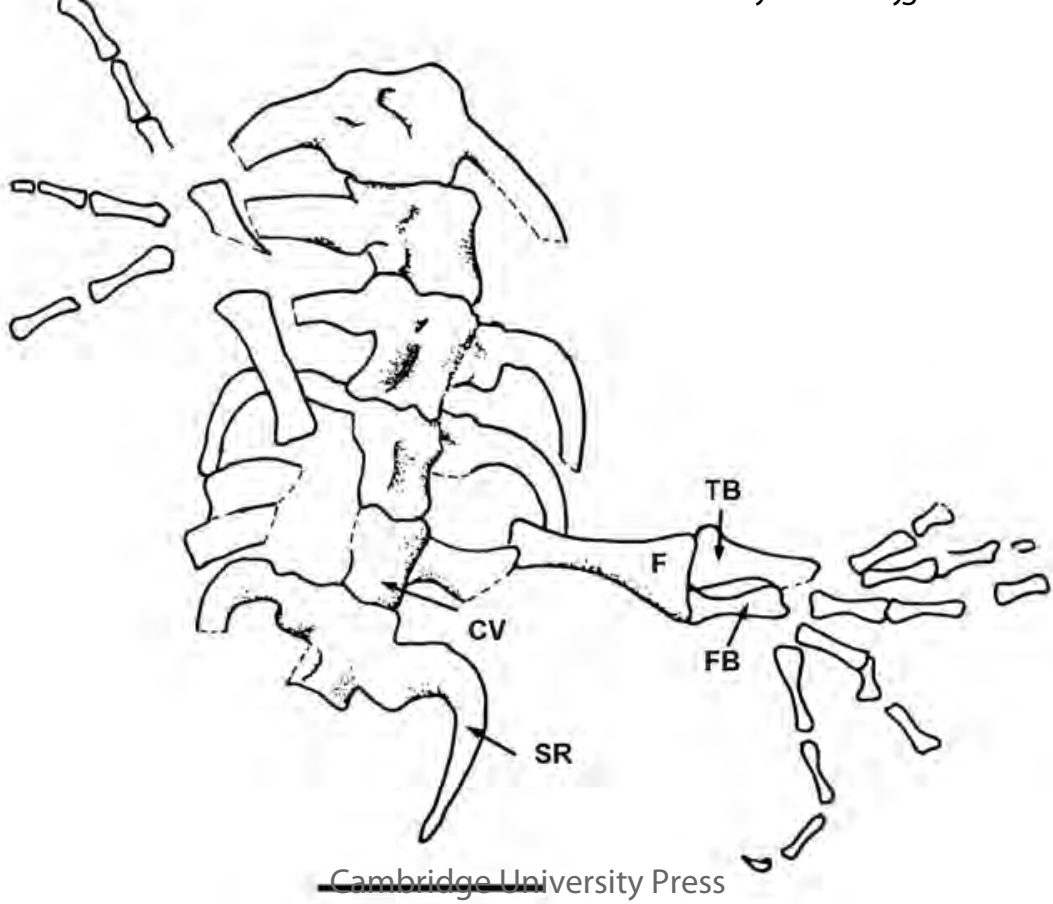




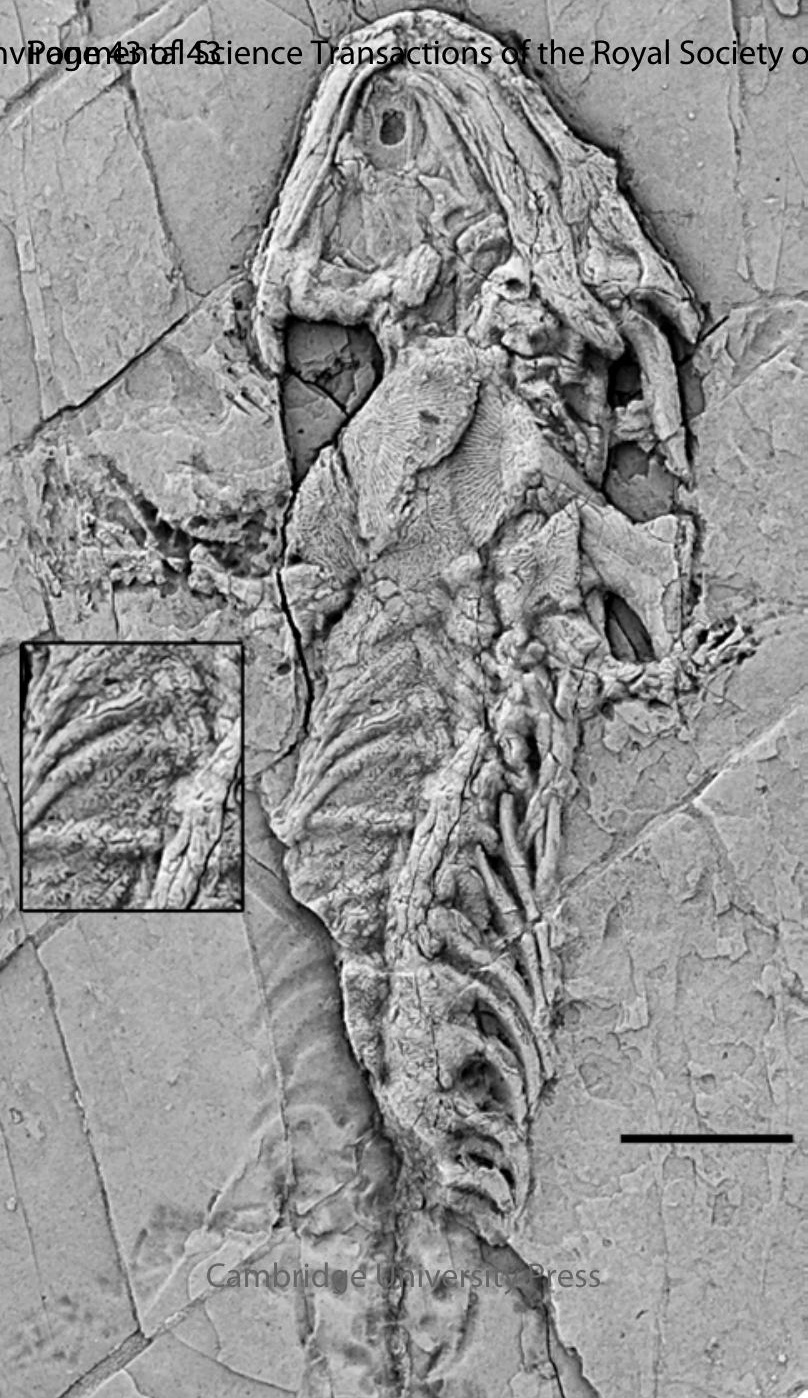

